\title{
A Study on Risk and Expense Evaluation of Agility Supply Management of Machinery
}

\author{
Mohammad Heydari ${ }^{1}$ and Kin Keung Lai $\mathbb{D}^{2}$ \\ ${ }^{1}$ School of Economics and Management, Nanjing University of Science and Technology, Nanjing, Jiangsu, China \\ ${ }^{2}$ College of Economics, Shenzhen University, Shenzhen, China \\ Correspondence should be addressed to Kin Keung Lai; mskklai@outlook.com
}

Received 4 November 2019; Revised 15 February 2020; Accepted 2 May 2020; Published 19 May 2020

Academic Editor: Xiaohua Ding

Copyright ( ) 2020 Mohammad Heydari and Kin Keung Lai. This is an open access article distributed under the Creative Commons Attribution License, which permits unrestricted use, distribution, and reproduction in any medium, provided the original work is properly cited.

\begin{abstract}
We provide a technical assessment and critique of the existing literature via highlighting problems associated with conceptualization and technical improvement of agility practices. By presenting a narrative evaluation of the technical review, we underscore the nature of the SC hazard in addition to agility practices and furnish a synthesis for future studies. The purpose is to examine the relationship between identifying and ranking the elements affecting supply management for SC agility in compressed natural gas pressure vessels. This study is applied research and data are collected based on descriptive survey. The populace of the investigation is milled compressed natural gas pressure vessels. Survey data are amassed through interviews and questionnaires. Cronbach's alpha has been utilized to evaluate the reliability of the values received 0.778 , which shows that the questionnaire is of excellent reliability and the questionnaire has 27 questions. Also, because the volume of the statistical population is 270 people, the consequences show that there is a positive connection among the empowerment of SC agility. Driving agility is on a positive supply chain (SC) agility. The expense has a poagilitysitive impact on SC agility.
\end{abstract}

\section{Introduction}

A successful strategic decision offers the right move for the exact markets at the exact time. SWOT evaluation is a commonly utilized tool that tests the strengths and weaknesses of an organisation or industry along via occasions and threats in the market environment. The SWOT frame offers primary definitions for evaluating the performance of selected positions. In this study, without assigning significant rankings to the SWOT elements, we suggest to decorate the SWOT evaluation with MCDM strategies known as AHP and ANP. The AHP algorithm compares priorities between elements or requirements to prioritise each level of the hierarchy by computing eigenvalues. In addition, for the AHP, the ANP algorithm is a common form that allows for interdependencies, exterior dependencies, and feedback between the determinants of hierarchical or nonhierarchical structures. The main reason for current article is to describe how AHP and ANP strategies are used to prioritise and evaluate SWOT factors.

Increased rivalry in the decade 1990 organisations will have to enhance the efficiency in many factors of its business. That is why industry leaders have realized that it is now not adequate merely to produce a quality product; however, additionally, to supply products in accordance with the demands of the customer (when, where, and how), the quality and expense are cared for. In such circumstances, located organisations have to manage the units that provide inputs as well as delivery and after-sales service centres linked to the product to the customer and pay.

Today's worldwide business environment is characterised via a short product life cycle, worrisome consumer needs, and varying provide link hazards. In this environment, organisations are looking for new ways to deal with hazards and provide better link performance. Many transactions are characterised by the universal technique 
of planning and supplying, products, services, and information related to the provided link. As these exchanges and strikes unfold for the collection of retailers and subsequently student consumers, we try to align events [1].

The following definition for "provide link management" (SCM) offers similar clarification: "provide link management is the coalition of essential business procedures from the final user through the main suppliers that current goods, services, and data add value for clients and different stakeholders" [2].

By looking at providing links from the perspective of a structure, many of J. Förster's insights are equally relevant. As stated by Forrester [3], a complex toy is a "high order, larger than a ring, and nonlinear response structure." Response and nonlinearity are critical things that can lead to "counter-attack" behaviour in complicated systems [3].

These days, business organisations face challenges, occasions, and threats to fulfill their mission. Managers usually appear to be in a holistic view of the current state of the organisation and evaluate its future status with respect to the interior and exterior environment [4]. Describing interior strengths and weaknesses, precisely as occasions and exterior threats, is based on a technique known as SWOT evaluation (strengths, weaknesses, occasions, and threats) [5]. SWOT evaluation is a common algorithm for examining both environments until a systematic strategy is achieved and DM is aided. Also, SWOT has no means of recognizing the importance of elements or evaluating decision-making options with respect to the elements. Within the current research, a quantitative-relay on SWOT assessment for the systematic prioritisation of SWOT elements is shown. The proposed algorithm is acquired via performing the AHP and ANP.

Overall, this article seeks to answer this question:

Are the identification and ranking of factors affecting supply management for supply chain agility CNG pressure vessels having a relationship?

1.1. Research Questions. So many provide link managers are looking for ways to enable them to better assess their provide link dexterity. Unfortunately, in the literature, there is no common frame and natural system for defining and measuring provide link dexterity.

So, we can form research questions (RQ) as follows:

RQ1: how should SC dexterity be defined?

RQ2: what are the aspects of the business SC dexterity construct?

RQ3: how is dexterity unique from nearly associated terms such as flexibility, responsiveness, adaptability, and resilience?

RQ4: what are some of the strategic-level precedents of the business that provide link dexterity?

RQ5: what is the connection among business provide link dexterity and its strategic-level antecedents?

\section{Related Research}

SWOT evaluation has no more extended supply capability of systematically figuring out the relative magnitude of the standards or to verify choice options by these criteria. To counter this failure, the SWOT frame is transformed into a hierarchical/network structure, and a mannequin is built and the use of AHP/ANP is analyzed.

The purpose of using AHP and ANP in the SWOT algorithm is to systematically validate the SWOT elements and their intensity equations [6]. The suggested method is used in three stages [7]:

Level 1: this level is to list the interior (exterior) strengths and weaknesses (occasions and threats) for strategic planning and assessing the SWOT assessment.

Level 2: at this level, pairwise analogy is made to compare the domains of every SWOT group.

Level 3: this level utilizes AHP to obtain the related preferences of every component in the SWOT teams. Then, the final weight degree of the elements is acquired by multiplying the local weight elements via the weight of the individual group.

The suggested algorithm is as follows. To practice ANP operations on the matrix to decide on the priorities of many SWOT elements [8]:

Level 1: recognize SWOT elements.

Level 2: note that there is no dependency between the SWOT elements. Understand the important steps of SWOT elements on a scale of 1-9.

Level 3: recognize the dependency matrix of all the SWOT components according to different factors using the dependency schema between the SWOT elements.

Level 4: recognize the established priorities of the SWOT elements.

Level 5: recognize the nearby significance levels of the SWOT subelements via a 1-9 scale.

Level 6: recognize the worldwide significance levels of the SWOT subelements.

Numerous scientists have investigated the problem of establishing a quantitative rely on SWOT assessment with AHP. Kurttila et al. created an interior SWOT evaluation via the AHP to make the elements unbearable and to assist in slightly higher fundamentals in strategic planning $[9,10]$. This positive algorithm has been widely used and studied in various areas. From the perspective of the programs, the built-in SWOT-AHP algorithm has been utilized to make decisions about outsourcing choices for sports advertising [11] and to evaluate management techniques of a forest property [12], see [6, 7, 12-19].

Minimal studies are in contrast to SWOT-AHP programs with ANP-based SWOT evaluation. Yüksel and Dağdeviren used SWOT contrast and ANP combined mannequins to choose the algorithm desired for a textile company [8]. Azimi et al. 2011 used the ANP embedded in SWOT to assess the cumulative impact of pollution on 
climate management. Azimi et al. suggested a combined mannequin for prioritising Iran's mining techniques. They used ANP to gain weight for SWOT agents [4]. Ostrega et al. reduced the ANP method, which mainly relies on the SWOT method, to reduce the environmental effects of mining activities [20]. Fouladgar et al. proposed an interior mannequin via ANP to use the weight of SWOT elements [21]. Foroughi et al. (2012) improved a method for prioritising Islamic Azad University strategies using SWOT evaluation with ANP algorithm.

2.1. What Are the Advantages of SWOT, AHP, and ANP Models? AHP performs pairwise analogy among assessment elements to prioritise the use of the eigenvalue counted. In an ordinary SWOT evaluation, the weightiness of the elements is not quantified to recognize the impact of every component at the suggested approach options [8]. A SWOT evaluation does not offer manner of systematically recognizing the related importance of the specification or to evaluate decision options consistent with these specifications. With a purpose to handle this inadequacy, the SWOT schema is transformed into a hierarchic shape and the mannequin is combined and the usage of the AHP is analysed via its eigenvalue computation technique [22].

The goal of using the AHP in the SWOT algorithm is to systematically be eligible for SWOT elements and equate their intensities [23]. The suggested technique is implemented in three levels [24]:

(i) The first level is to list the significant interior (strengths and weaknesses) and exterior (possibilities and threats) elements for the strategic planning, making up the SWOT evaluation.

(ii) Within the second level, the pairwise analogy is applied to seize the weights of every SWOT organisation.

(iii) In the end, the third level utilizes the AHP to derive the related preferences of every component inside the SWOT agencies. Then, the general element weight rank is received by multiplying the elements of nearby weights with the particular organisation weight.

Despite the fact that the AHP method gets rid of the deficiencies intrinsic within the dimension and assessment steps of SWOT evaluation, it does not analyse the feasible dependencies and responses between the SWOT elements [25].

Whenever AHP has been very famous, ANP is less distinguished inside the context [26]. ANP mannequin is an improved model of the AHP technique, which precisely describes the connections in complicated mannequins that use many scales, responses, and interdependences among the scale. A bonus of this approach is that it easily describes the DM issue which contains many complex relationships. ANP approach explains all ingredients and connections as bidirectional interactions. ANP consists of connections among individual clusters at unique hierarchical tiers, in addition to the interactions among criteria and subscale, consequently, this technique is beneficial for acquiring more correct and effective outcomes in DM in complicated structures.

AHP and ANP are famous techniques additionally due to the fact that they have got the ability to become aware of and examine the inconsistencies of DMs in the procedure of discernment and assessment of the factors of the hierarchy [27]. If the amounts of the weight coefficients of all the factors which might together contrast at a given hierarchy stage could be precisely diagnosed, the eigenvalues of the matrix A could be completely steady; however, that is exceptionally hard to accomplish in exercise. Consequently, the implementation of these strategies affords the potential to analyse mistakes of arbitration via means of calculating consistency index (CI) for the received analogy matrix $A$ and then to compute the consistency ratio (CR) [28],

$$
A=\left(a_{i j}\right)_{n \times n}=\left[\begin{array}{cccc}
a_{11} & a_{12} & \ldots & a_{1 n} \\
a_{21} & a_{22} & \ldots & a_{2 n} \\
\cdot & \cdot & \cdot & \cdot \\
a_{n 1} & a_{n 2} & . & a_{n n}
\end{array}\right] \text {, }
$$

on the closing step, and every matrix is normalised and the related weights are observed. The relative weights are given via the exact eigenvector $(\mathrm{w})$ similar to the most important eigenvalue as follows:

$$
A w=\lambda_{\max } \cdot w
$$

If the pairwise analogy is absolutely steady, the matrix $A$ has rank 1 and $\lambda_{\max }=n$. for the current situation, and weights may be acquired via normalising any of the rows or columns from $A$ ([29-31]). It must be stated that the quality of the output of the AHP is associated with the stability of the pairwise assessment arbitrations. The consistency is described via the connection among the entries of A: $a_{i j} X a_{j k}=a_{i k}$ [32]. The CI index can be counted, using the following formula [33]:

$$
C I=\frac{\lambda_{\max }-n}{n-1}
$$

The usage of the latest CR can count whether the analysis is enough and stable. The CR is computed as the proportion of the CI and the RI, as illustrated in (4). The range 0.1 is approved higher restriction for CR. If the latest CR surpasses this value, the assessment process needs to be reiterative to enhance consistency (see Table 1):

$$
\mathrm{CR}=\frac{\mathrm{CI}}{\mathrm{RI}}
$$

2.2. SC Modeling and Agility. The modeling concept used for provide link management (DFSCM) and via HewlettPackard (HP) was first illustrated by [35] and is further described by Lee [36]. According to these sources, the idea of the Design for Supply Chain Management was once at HP in the beginning 1990s. The main problems that were addressed are roster problems and are built on an international provide link inventory model [35]. Many provide 
TABle 1: Random index (RI) [34].

\begin{tabular}{lcccccccccc}
\hline$n$ & 1 & 2 & 3 & 4 & 5 & 6 & 7 & 8 & 9 & 10 \\
$\mathrm{RI}$ & 0.00 & 0.00 & 0.58 & 0.90 & 1.12 & 1.24 & 1.32 & 1.41 & 1.45 & 1.49 \\
\hline
\end{tabular}

link strategies aimed at the different provide link problems that HP was trying to solve and were incorporated into the Hewlett-Packard DFSCM. Among the list of provide link strategies are the follows:
(i) Delayed product differentiation
(ii) Commonality
(iii) Standardisation
(iv) Procedure level switching
(v) Procrastination [35, 37-40]

Many of these techniques or ideas are goaled at amenability, dexterity, and expense decreasing. The first of the problems raised by HP were the elements involved in product modeling, stock placement, and charting for local markets [37].

In addition, DFSCM is characterised via the establishment of evaluation groups and the use of training scholars to direct or addendum sources inside HP [39, 41]. One of the DFSCM crew members is explained as "finance, marketing, production, distribution, and engineering" [39, 41]. This interoperability is an essential element in achieving integration within provide link operations. Interior integration is recommended as an essential requirement to help provide link dexterity. Sufficient time for evaluation is any other significant component that characterises the HP DFSCM method [39, 41, 42]. Among the participants in the training, Dr. Howe Lee of Stanford was the most outstanding contributors in the HP initiative, but other academics have also participated. The advantages of this industry-university partnership are no longer underestimated. The education may additionally deliver particular know-how in one or higher analytical strategies and greater importantly the tutorial might also convey lessons obtained from different business corporations, which may not be on hand with the aid of HP management. Those examples are the primary advantages predicted while character instances might also additionally lend different advantages from enterprise and academia working together.

2.3. Agility and Risk in SCM. Dexterity in the provided link is explained as being in a position to "respond to surprising and surprising modifications in markets. Dexterity is necessary because, in most industries, each demand and supply fluctuate more swiftly and widely than they used to. Most provide links that cope with using and enjoying speed towards expenses. However, active ones respond both quickly and cost-efficiently" [41]. A one-aspectual feedback via an organisation is not applicable and does not constitute dexterity. Natural resources of provide link hazard to overall performance have been investigated beforehand, such as location, transportation, arranging the orders, purchasing, quality, provide lead time, supply accessibility, and demand $[35,43,44]$.
Rivalry from an agile landscape rely on companies being able to properly adapt their provide links while building healthy connection via clients and suppliers [45]. Provide link dexterity will be the key to accepting change in the market by making more effective use of integration with suppliers effectively [46]. As other agencies pursue production capacity using outsourcing or out-of-siege, unique supply factors increase.

Agility is a rising time period, which means a certain connection among an enterprise and its market. Indeed, agility is a set of capabilities for assembling extensively numerous client necessities in phrases of price, specification, quantity, quality, and delivery [47]. Hence, agile production pertains to businesses coping with risky market demand by permitting changes to be generated in an economically possible and timely way [48]. Although a great quantity of study has been carried out in the location of supply chain planning (SCP), the context is basically missing in presenting an analytical version to solve the issue of agile production operating in a BTO (Build-To-Order) environment. Assumption of build-to-order (BTO) producing techniques in the marketing function has been increasingly implemented in a huge diversity of industries, from car producing to computer belongings to furniture. Considering the concept of agile manufacturing, the developed multiproduct, multiperiod, multiechelon mixed-integer linear programming model is then solved using CPLEX optimization studio and guidance related to future areas of research is given.

In a try for filling this gap, a mathematical mannequin for midterm SC planning of an agile production organisation running in a BTO environment is enhanced. The primary goal of this research is to formulate a revolutionary mathematical mannequin for multigoods, multiperiod, and multiechelon SC planning of a BTO frame that combines suppliers, producers, broadcasts zones, and client centres utilizing the MILP technique. Consistent with the literature, this research is one of the first studies performed on SCP issues of agile production in a BTO environment.

2.4. SC Agility and Risk Algorithm. To modeling dexterity in the provided link, cross-application teams must reflect attention to a wide range of hazards (see Figure 1). A wide range of hazard involves complexity. Demand fluctuation, supply fluctuation, and dominant supply chain happens (contingency planning and SC event preparedness). These previous comments and discussions for the current article have been integrated to enhance the following mannequins for supply chain dexterity and hazard [49].

This algorithm contrast from many of the important issues of provide link dexterity in the provide link context. Various strategies that HP employs include "agile fit approaches" but are basically "suitable" for "SC variability." Therefore, the suggested algorithm contains delineating strategies from other resources and expanding hazard factors beyond the usual definition of an environment where provide link dexterity is required. "Major SC events" needs rigorous and agile techniques and requires extensive 


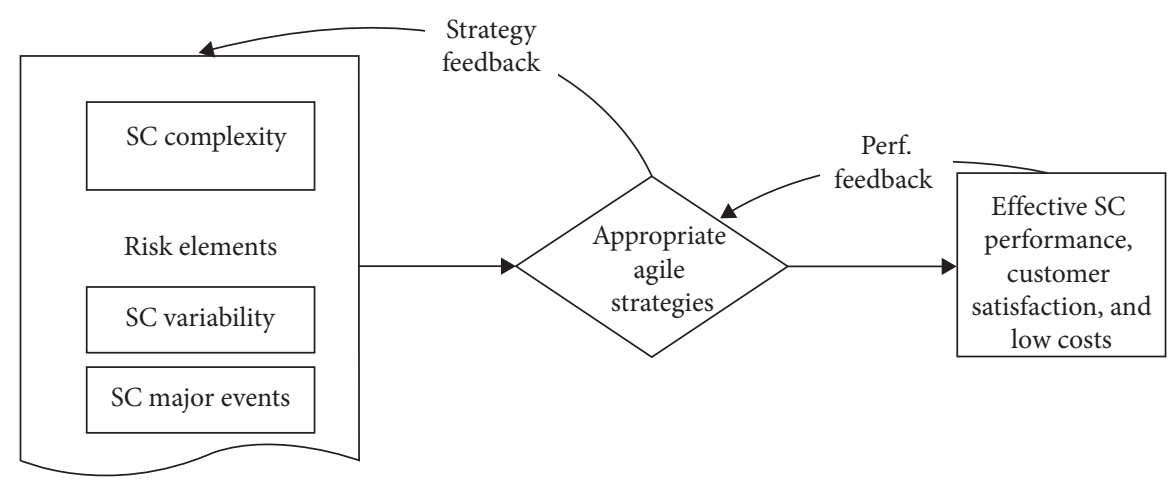

FIGURE 1: Modeling for SC risk algorithm. Source: accepted by Monroe and Martin, 2008 [49].

planning, situational assessment, and functional groups to prepare probable plans. "SC intricacy" is another important hazard factor that should be distinct as "SC variability" and "SC important happens." Provide link rationalisation, strategic alliances, and long-term "evergreen" conventions are a few instances of techniques that may be used to counter " $S C$ intricacy" [50].

\section{Conceptual Overview in the Literature}

Because of the "unionist view" of logistics and SCM, it is illustrated via Larson et al., and SCM can be considered as "broad" and "deep." SCM is significant because it has business functions such as production, marketing, and transportations. SCM is thick because of the fact that it covers strategic, tactical, and operational management departments $[51,52]$. The strategic part of SCM is about the decisions that are made by a company that has a long-term impact. These contain decisions on outsourcing, supplier election, and location of the warehouse and factory [53]. The key factor in this area is choosing the right SC strategy based on goods and market needs. To date, no definitive consensus has been reached on how to describe a range of techniques. Strategic scrutiny of SCM is largely hindered because there is no perceptual clarity of applied techniques. To assist compensate for this absence, an overview of the literature is presented, which goals to explore the perception of the four mains that provide link strategies: dexterity, robustness, resilience, and flexibility.

3.1. Robust SCs. In a broad sense, provide link robustness may, in addition, be regarded as the capability to cope with any deviation or forecasting [54]. Pursuant to Meepetchdee and Shah, it has been described that the SC can increase its performance despite some of the damage to it, for example, attack $[55,56]$. The robust SC maintains the same stable scenario that has emerged in the past from changes [57], and its techniques are not sensitive to noise factors [58]. Therefore, a reliable provider link will resist rather than responding to changes. To this end, the provide link diagram attempts to configure the provide link infrastructure so that it can function properly in the widest possible range of demand possibilities [59]. Tang proposes nine examples of robust provide links whose goals are to enhance the ability to manage supply or demand better under normal conditions as well as performance and to maintain operations during the forecasting. Many of these incentives are the paradigm of mixing additional sources in the provided link, namely, additional modes, carriers and transport routes, new stocks, and additional suppliers. As follows, provide link robustness can generally be rooted in its redundancy [60, 61]. Redundancy in the foundation is achieved by investing in capital and potential before the need arises [62]. Not completely redundant sources, but reliable sources also contribute to robustness. It can, therefore, enhance the power by raising concerns of relevant gamers to provide link modeling [63]. The following definition is provided.

3.2. Resilient SCs. As stated by Asjjørnslett [57], flexible structures can be adapted and, therefore, resilience may be illustrated as the potential of a system to return to a new stable state after an unintended event. Ponomarov and Holkeb explained it [64]:

[.... the adaptive ability of the provided link to bring unexpected incidents together, respond to disruptions, and improve them via keeping the optimal continuity of operation and connecting and manipulating shape and performance.

However, those descriptions blur the obstacles among dexterity and resilience. The unique view is organised using Rice and Kaniato and Shafi and Rice who think of two ways to create flexibility and redundancy $[62,65]$. This performance is supported by Stuart et al. [66], which affected the ability to influence redundancy, stability, and plasticity. Flexibility is an integral section of dexterity, while redundancy is a key part of strength. Not surprisingly, numerous flexible concepts affect the resilience of a mixture of dexterity and strength. Tang explained resiliency is a technique that allows operations to be maintained in some stages with fullscale disruption and then rapidly improved. Christopher and Rutherford states that "the flexible provide link is certainly robust" and a "provide link is additionally adaptable $[60,67]$." "The ability of a system to return to its original kingdom or to move to a new and more ideal postturbulent 
state" [67, 68]. Fiksel points out that flexibility helps each person to continue living and adjusting. For this reason, the provide link can resist if its status quo is stable, or if a new secure scenario runs as long as provide link can go back "with one disruption." "The following definition is suggested [69].”

3.3. Adamant SCs. In other words, performance is the right thing to do, while doing the right thing [70]. Efficiency has been perceived as an accountability garrison (Fisher, 1997) or dexterity (Lee, 2002). However, antibody efficacy is now not flexible, as resistance or response sources can also be "right things" to do in specific situations as well as being lean, which is a crucial time period in SCM construction. In [71, 72], the antidote is considered dexterity $[40,73,74]$. Given that antibody lean is not flexible, lean is aimed at reducing lead samples and using fabrics. However, a lean provide link must be in a position to quickly feedback. Therefore, the term "stiffness" is regarded as a resistance antibody.

3.4. Strategy Selection. Before presenting an algorithm that assists, select the most appropriate technique between the four provide link techniques already delivered, and it is helpful to give a quick overview of the strategy election. The new proposition is relied on the big difference among useful and innovative manufactures. In contrast to revolutionary goods, useful goods have a long manufacture life cycle, low manufacture range, and long durations. Demand for useful goods is very natural to predict when it comes to new products. Fisher stated that an applied manufacture needs an environmentally friendly provide link strategy, whereas progressive goods require a responsive one [73]. In nature, it is essential to shape provide link techniques with commodities [75].

Managing demand and supply uncertainties is essential for all producers [76]. Lee shows that supply and demand uncertainties are crucial about this technique. Effectiveness is appropriate for products with low demand uncertainty (applied products) if there is low supply uncertainty (sustainable process) [40]. In the event of severe supply uncertainty, the hazard protection for these products is amazing. To be responsive is to supply goods with the uncertainty of high demand (innovative products) in the event of uncertainty in low supply. The dexterity of oversupply uncertainty for these commodities is very terrible [77].

This distinction is made among lean, agile and "fragile" techniques. In their classification, Christopher et al. have guided lead refill loads and demand forecastable/volatility to guide appropriate provide link techniques. Christopher and Tavil suggest three fragile algorithms [40]: joining the Pareto curve, coupling agent coupling strategy, and separating "base" and "incremental" demands.

In these algorithms, extraordinary parameters are used to solve the supply strategy. Fisher focuses on the uncertainty hazard of predicting demand for innovative goods [73]. Lee also regards the hazard of supply-aspect uncertainty. Christopher et al. emphasise the importance of hazard arising from short-term cases in choosing the right strategy [78]. In principle, all algorithms concentrate on supply and demand hazards, but they do not explicitly deal via the other hazards considered in SCRM now.

\section{Development of Theories and Conceptual Algorithms}

Today, the provide link has become a critical factor in global markets so that, in the global arena, the main rivalry provided a link. Stadler grants the chain network of organisation-related upstream to downstream be aware of the processes and activities involved and the products and services provided to the cease customer and create value. On the contrary, the provided link consists of two or more organisations that the flows of materials, records, and money are interrelated to [79].

Supply-chain management and warehouse administration are the result of the evolution. This concept was brought in the early 1990s and due to the globalization of markets, increased rivalry has become more critical [79].

One of the paths to enhance the performance of organisations in manufacturing, service, and achieving a competitive advantage is the efficient management of the provide link. Creating an integrated provide link makes a competitive advantage for the organisation. Supply-chain management contains all the activities that link suppliers, distributors, and customers to apply the exact quantity and at the exact time and place the goods, to minimize system expenses and maximize customer service levels, produced and distributed. In other words, the provided link is the result of combining different operational circles at the beginning and the end of its suppliers and customers (see Eq. $(5,6)$ for more information about the conceptual algorithm.)

In the current research, an SC network which includes suppliers, production gas (CNG) pressure vessels, forecasts zones, and client centres is regarded. In general, the BTO SC operates as a demand fulfilling approach of SCs that are concerned in assembling customised goods. Within the suggested BTO system, common component sections are fabricated relay on a short-term distribution of client demands, while latest customised goods are illustrated after receiving approved demand orders. The primary purpose of the suggested mannequin is to understand the procurement plan, manufacturing plan, inventory stage, transportation plan, and backorder quantities on every occasion length of the planning horizon for every echelon covered in the SC. The goal of the advanced mannequin is to minimize the overall working fees while maintaining the preferred customer support stage. The mannequin is improved for businesses that benefit from the advantages of being agile to diversified client alternatives for goods [80]. Agility, which is a mixture of pliability and responsiveness, is an essential need for those producing businesses that need to enhance their market proportion and survive over their competitors. Gratifying variety of consumer needs at the shortest feasible time while displaying quick feedbacks to converting market situations causes production gas (CNG) pressure vessels to supply standard sections and components relay on predicted demands of historical information. However, custom 
designed goods will not be manufactured till the latest demands are revealed via certainty. The subsequent notations and criterion are used in the formulation of the mannequin.

This study, a single-goal characteristic of minimising the entire SC operating fees, is enhanced, while keeping the preferred customer service stage:

$$
\begin{aligned}
\mathrm{RC}= & \sum_{t} \sum_{r} \sum_{v} \sum_{f} \mathrm{RC}_{r v t} \cdot \mathrm{RTQ}_{r v f t}, \\
\mathrm{PC}= & \sum_{t} \sum_{n} \sum_{p} \sum_{f}\left(\mathrm{NGC}_{n f t} \cdot \mathrm{NGQ}_{n f t}+\mathrm{NOC}_{n f t} \cdot \mathrm{NOQ}_{n f t}\right. \\
& \left.+\mathrm{GC}_{p f t} \cdot \mathrm{GPQ}_{p f t}+\mathrm{OC}_{p f t} \cdot \mathrm{OPQ}_{p f t}\right), \\
T_{S} C= & \sum_{t} \sum_{r} \sum_{v} \sum_{f} \mathrm{RTC}_{r v f t} \cdot \mathrm{RTQ}_{r v f t}, \\
I_{r} C= & \sum_{t} \sum_{r} \sum_{v} \mathrm{RHC}_{r f t} \cdot \mathrm{RIL}_{r f t}, \\
I_{n} C= & \sum_{t} \sum_{n} \sum_{f} \mathrm{NHC}_{n f t} \cdot \mathrm{NIL}_{n f t}, \\
T_{p} C= & \sum_{t} \sum_{r} \sum_{f} \sum_{w} \mathrm{WTC}_{f w t} \cdot W T Q_{p f w t}, \\
I_{p} C= & \sum_{t} \sum_{p} \sum_{w} \mathrm{PHC}_{p w t} \cdot \mathrm{PIB}_{p w t}, \\
T_{w} C= & \sum_{t} \sum_{p} \sum_{c} \sum_{w} \mathrm{PTC}_{c w t} \cdot \mathrm{PTQ}_{p c w t}, \\
\mathrm{BC}= & \sum_{t} \sum_{p} \sum_{c} \mathrm{BC}_{p c t} \cdot \mathrm{BQ}_{p c t},
\end{aligned}
$$

$$
\begin{aligned}
\text { Min Total Cost }=\operatorname{Min} Z= & \operatorname{Min} \sum\left(\mathrm{RC}+\mathrm{PC}+T_{S} C+I_{r} C\right. \\
& \left.+I_{n} C+T_{p} C+I_{p} C+T_{w} C+\mathrm{BC}\right) .
\end{aligned}
$$

The total operating cost $Z$ confirmed in equation (6) includes nine combination cost components that exist in every SC participator including raw material supply, transportation, and storage fees, ordinary time and extra time cost of manufacturing, product inventory holding fees, transportation fees, and shortage penalty fees. The mannequin indices are described in Table 2.

\section{Methodology}

The aim of this research is that applied research is collected as a descriptive survey research data. In this study, descriptive statistics (average, variance, etc.) to describe the population and inferential statistics for the evaluation of the components $t$-test to recognize the notability of the difference between the mean and also confirm or reject hypotheses was used. The population of this research was to mill Compressed natural gas (CNG) pressure vessels. Recent survey data collected through interviews and questionnaires show that Cronbach's alpha has been utilized to analyse the reliability of a value which is obtained as 0.778 and indicates that this is reliability indexes. Furthermore, this study is to examine the validity of the methods.
TABLE 2

\begin{tabular}{lr}
\hline$v$ & Suppliers, $v=1,2, \ldots, V$ \\
$r$ & Raw materials, $r=1,2, \ldots, R$ \\
$f$ & Gas (CNG) pressure vessels, $f=1,2, \ldots, F$ \\
$n$ & Component sections, $n=1,2, \ldots, N$ \\
$p$ & Final goods, $p=1,2, \ldots, P$ \\
$w$ & Forecasting zones, $w=1,2, \ldots, W$ \\
\hline
\end{tabular}

It should be noted that the questionnaire contained 27 questions. In addition, because the volume of research population is 270 people, given the number of variables and questionnaires using the range Q15>N>Q5, selected samples of 200 people were taken.

5.1. SWOT-AHP Algorithm. The AHP compares the two elements with the elements of evaluation in order to prioritise them using a basic preliminary computing. Usually, by SWOT evaluation, the weight of these elements is no longer recognized to recognize the impact of every component on the suggested technique options [8]. SWOT evaluation does not report means of systematically identifying the relative importance of specification for determining selection options pursuant to these criteria. To address this failure, the SWOT frame is transformed into a hierarchical shape and built into an algorithm that analyzes the use of AHP using the EQ methods [81, 82].

The purpose of using AHP in the SWOT frame is to systematically qualify SWOT agents and equate their intensity [6]. The suggested approach is used in three stages.

The first level is to list the key factors (strengths and weaknesses) and exterior opportunities (occasions and threats) for strategic planning, preparing a SWOT evaluation.

The second level uses pair analogy to compare the weight of every SWOT group.

At the end, the third level utilizes the AHP to obtain the related priorities of every component in the SWOT groups. Then, by multiplying the local weight elements via the weight of the particular group, the total weight rating of the elements is achieved.

Kurttila et al. [9] created an interior SWOT evaluation through the AHP to support elements of uncertainty and to support a less basis in strategic planning [10]. This improved technique has been widely used and studied in various areas. From the perspective of programs, the combined SWOT AHP approach has been utilized to identify outsourcing decisions (see $[6,7,11,13-19]$ ).

5.2. Application of These Algorithms. The main idea behind using AHP/ANP in the SWOT shape is to regularly evaluate the SWOT elements and their structure commensurate with their weight [12]. Saaty performed a comparative scale for pairwise analogy and identified the relative significant among every pair of SWOT element [83]. After digitizing the SWOT frame through AHP/ANP, it is available to achieve vector weights or priorities for the teams and elements through the obtained matrix. 
Hierarchical and network algorithm which is encouraged for SWOT evaluation has four levels that the best strategies have been identified at first stage, SWOT group elements are at the second stage, then the sublements of SWOT matrix have been analysed, and at last alternative options or strategies have prioritising base on their value.

To generate a SWOT-AHP/ANP-based algorithm, the following three sections' algorithm is modelled: constructing an initial task, enhancing elements, and constructing an evaluation algorithm (see Table 3 and Figure 2).

In the first step, a SWOT evaluation is carried out, and the matrix is structured. Elements related to the exterior and interior environment of the company are illustrated and constructed in the SWOT matrix. Four specialist and company management personnel have helped build SWOT factors from their knowledge and experience. The AHP (see Figure 3) applies to the SWOT matrix. Below is the traditional hierarchical structure of AHP [46].

Secondly, pairwise analogy of the SWOT organisations, utilizing Saaty's analogy scale, is built [33]. The assessment result is proven in Tables 4-8. SWOT elements are compared regarding each SWOT organisation. All pairwise analogy within the application are completed through the professional organisation. They chip in their professional experience to construct the analogy matrices for the network method.
At the end, the final priority rescores of SWOT elements are computed. Final priorities are proven in Table 9. The AHP evaluation outcomes indicate "growing the standards and increasing contemporary technology" are the maximum important problems considering a (CNG) producers interior and exterior environments.

After the AHP evaluation, in this segment, the ANP algorithm is used. Interior dependence between the SWOT elements is extended by regarding the effect of each element over other elements using analogy matrices.

The existence of dependence between elements can be shaped via the ANP algorithm. The dependence between the SWOT elements is installed, that is, proven, skeptically in Figure 4 [33].

At this point, to apprehend ANP-associated with SWOT organisation priorities, pairwise analogy matrices are created; Figure 4 is needed to be taken into consideration (Table 10). Regarding the computed relative significance, the interior dependence matrix of SWOT elements is created. Every element of the SWOT is influenced via other elements so that $\mathrm{S}$ element is influenced by $\mathrm{W}$ and $\mathrm{O}$ elements, $\mathrm{W}$ issue is influenced by $\mathrm{S}$ and $\mathrm{T}$ elements, $\mathrm{O}$ element is influenced via $\mathrm{T}$ and $\mathrm{S}$ elements, and $\mathrm{T}$ issue is influenced via $\mathrm{W}$ and $\mathrm{O}$ elements [84].

$$
\text { Interior dependence matrix of SWOT elements }=\left[\begin{array}{cccc}
1 & 0.762 & 0.783 & 0 \\
0.722 & 1 & 0 & 0.643 \\
0.278 & 0 & 1 & 0.357 \\
0 & 0.238 & 0.217 & 1
\end{array}\right] \text {. }
$$

SWOT group priorities that were calculated regarding interior dependencies are illustrated as follows :

$$
\left[\begin{array}{cccc}
1 & 0.762 & 0.783 & 0 \\
0.722 & 1 & 0 & 0.643 \\
0.278 & 0 & 1 & 0.357 \\
0 & 0.238 & 0.217 & 1
\end{array}\right] \times\left[\begin{array}{l}
0.367 \\
0.146 \\
0.365 \\
0.123
\end{array}\right]=\left[\begin{array}{l}
0.382 \\
0.244 \\
0.255 \\
0.119
\end{array}\right]
$$

A new scenario related to priorities of SWOT agencies that happens regarding interior dependencies has essential differences compared with SWOT teams' preferences with the idea of independence. The findings' variations are from 0.367 to $0.382,0.146$ to $0.244,0.365$ to 0.255 , and 0.123 to 0.119 for the priority amount of elements $\mathrm{S}, \mathrm{W}, \mathrm{O}$, and $\mathrm{T}$, respectively.

Dependencies and feedbacks in various elements of SWOT agencies took under consideration the utilizing network structure. For instance, a few elements in threats' organisation can affect "low earnings for each units" element within the weaknesses' organisation (Table 11). Dependence between SWOT elements is identified by evaluating the effect of each element on every other element using pairwise analogy. After that the general priorities of the SWOT elements are calculated via multiplying the dependent priorities of SWOT organisations with the neighborhood priorities of SWOT elements. Extra suitable and realistic outcomes can probably be acquired by utilizing both the SWOT evaluation and the ANP [85].

A network shape of the SWOT-ANP mannequin is shown in Figure 5. The general priorities of the SWOT elements computed through the ANP are shown in Table 12. The ANP outcomes acquired from super decision application. Consistent with the ANP-based evaluation, the most essential SWOT element is "modern overseas market."

5.3. Comparing the AHP and ANP Outcomes. On this segment, the outcomes from the SWOT-AHP mannequin had been compared with ANP-based mannequin. The results display the subsequent AHP ranking of every SWOT group priority: strengths (group weight 36.7\%), possibilities (36.5\%), weaknesses (14.6\%), and threats (12.3\%). Consistent with the AHP-based evaluation, the most vital element in SWOT is "growing standards and enhancing contemporary technology" from the possibilities' group. This problem is the most critical element to be regarded with a final priority amount of 0.197. Other sizeable elements are ranked as 
TABLE 3: SWOT matrix.

Strengths (S)

(S1) innovative capacity

(S2) availability of resources and skills

(S3) quality of the product

(S4) expert management staff

(S5) reliability in marketplace
Weaknesses (W)

(W1) lake of performance measurement systems

(W2) nonflexible organizational structure

(W3) energy costs

(W4) labour costs

(W5) lake of accurate forecasting capability, (W6) logistics costs, (W7) lake of well-known own brands

Opportunities $(\mathrm{O})$

(O1) rising living standards and increasing modern buildings

$(\mathrm{O} 2)$ globalisation and the decreased trade barriers

Threats $(\mathrm{T})$

(T1) macroeconomic industry

(T2) competition

(T3) political instability and possible problems in regional geographical area, especially Middle East, (T4) different and changing international market mechanisms, (T5) strengthening environmental pressures, (T6) different standardisation requests of international customers, (T7) low income per unit

Source. Yang et al., 2009 [46].

Model of Proposed Methodology (Modified from Yang et al., 2009)

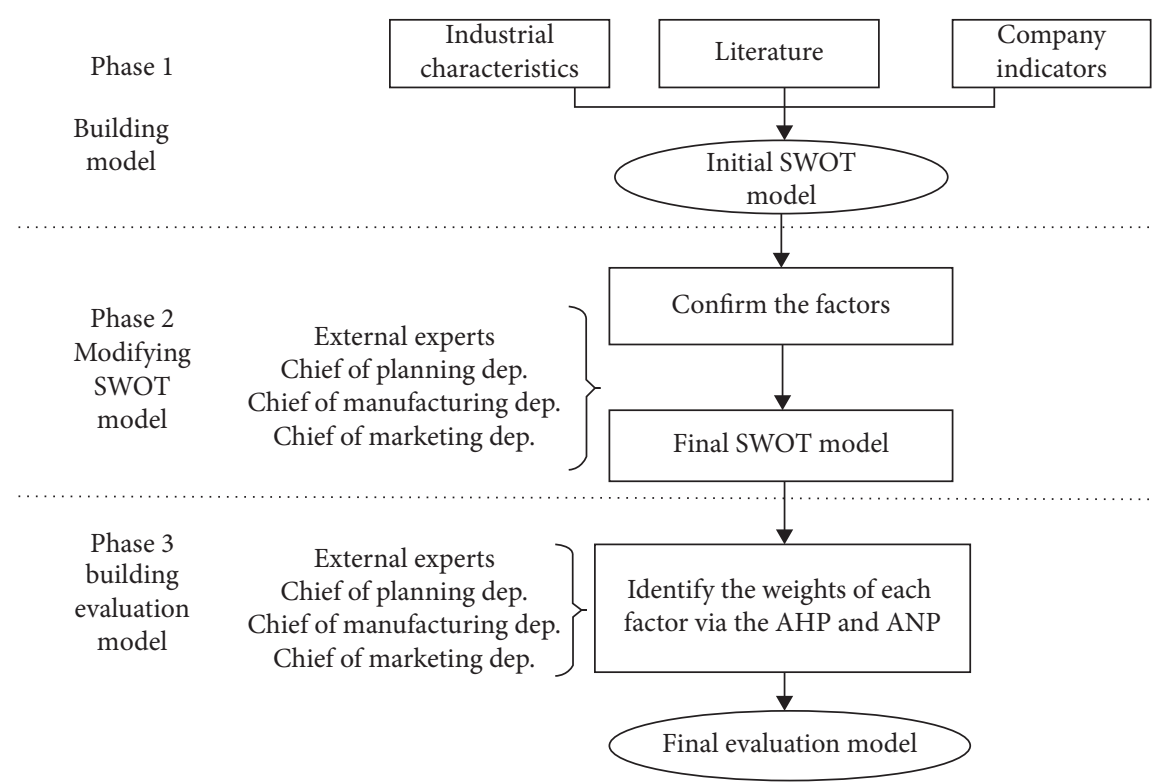

Figure 2: Algorithm of proposed methodology. Source: Yang et al., 2009 [46].

follows, consistent with priority: high quality manufacturers $(14.7 \%)$, cost of energy (4.3\%), labour fees (4.3\%), and opposition (2.9\%) elements. Within the ANP-based assessment mannequin, ranking of every SWOT group priority is as follows: strengths (group weight $38.2 \%$ ), possibilities (25.5\%), weaknesses $(24.4 \%)$, and threats (11.9\%). SWOT element priorities' amount is received via ANP, and the most significant element inside the evaluation is "new overseas markets" from the possibilities group via 0.183 common priority amount. Vital elements are ranked as follows, consistent with priority: goods condition (14.2\%), management of professional staff (11.6\%), feasibility of sources and competencies (9.5\%), and labour fees (7.7\%) elements. An assessment of effects indicates that there are enormous differences between AHP and ANP final results oriented from interdependencies, outer dependencies, and outcomes.
In this research, we have diagnosed considerable strategic elements to compressed natural gas manufacturing firms by integrating SWOT via AHP and ANP DM techniques. Utilizing counted preferences of SWOT elements can improve a management method or assist an essential decision. Moreover, this research's consequences could be used to form a suitable collection method option for the organisation. Future studies can enhance utilizing a fuzzy logic sketch via the AHP/ANP technique to more successfully analyse instances having uncertainty.

5.4. SC Strategy Expense Algorithms. Before improving the propositions that link provide link hazards and provide link strategies, there are expenses in adamant, agile, flexible, and hazard "chainsaws" that were previously selected as examples. 


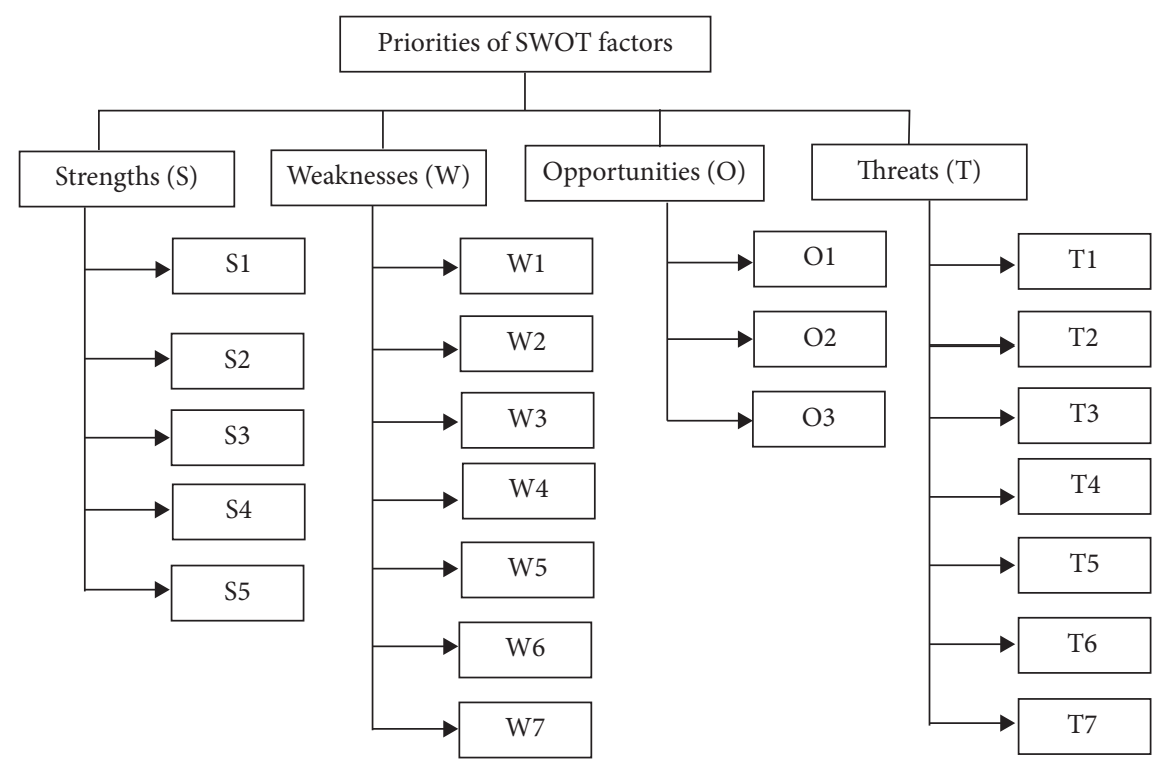

FIgURE 3: Hierarchical structural of SWOT-AHP. Source: Yang et al., 2009 [46].

TABLe 4: Pairwise analogy of strengths, weaknesses, opportunities, and threats (SWOT) elements.

\begin{tabular}{lccccc}
\hline SWOT group & Strengths $(\mathrm{S})$ & $\begin{array}{c}\text { Weaknesses } \\
(\mathrm{W})\end{array}$ & $\begin{array}{c}\text { Opportunities } \\
(\mathrm{O})\end{array}$ & Threats (T) & $\begin{array}{c}\text { Significant levels of SWOT } \\
\text { organisations }\end{array}$ \\
\hline (S) & 1.000 & 3.000 & 1.000 & 3.000 & 0.367 \\
(W) & 0.333 & 1.000 & 0.250 & 2.000 & 0.146 \\
$(\mathbf{O})$ & 1.000 & 4.000 & 1.000 & 2.000 & 0.365 \\
(T) & 0.333 & 0.500 & 0.500 & 1.000 & 0.123 \\
Consistency index (CI) $=0.06$ & & & & \\
\hline
\end{tabular}

TABLE 5: Analogy matrix of (S) group.

\begin{tabular}{|c|c|c|c|c|c|c|}
\hline (S) groups & Group (1) & Group (2) & Group (3) & Group (4) & Group (5) & Significant levels \\
\hline Original magnitude & 1.000 & 0.500 & 0.200 & 0.500 & 0.167 & 0.057 \\
\hline Available skills and resources & 2.000 & 1.000 & 0.167 & 0.200 & 0.167 & 0.065 \\
\hline Goods condition & 5.000 & 6.000 & 1.000 & 3.000 & 2.000 & 0.400 \\
\hline Management of professional staff & 2.000 & 5.000 & 0.333 & 1.000 & 0.200 & 0.144 \\
\hline Reliable market & 6.000 & 6.000 & 0.500 & 4.000 & 1.000 & 0.334 \\
\hline Consistency index $(\mathrm{CI})=0.08$ & & & & & & \\
\hline
\end{tabular}

TABLe 6: Analogy matrix of (W) group.

\begin{tabular}{|c|c|c|c|c|c|c|c|c|}
\hline$(\mathrm{W})$ groups & $\begin{array}{l}\text { Group } \\
\text { (1) }\end{array}$ & $\begin{array}{l}\text { Group } \\
(2)\end{array}$ & $\begin{array}{l}\text { Group } \\
(3)\end{array}$ & $\begin{array}{c}\text { Group } \\
(4)\end{array}$ & $\begin{array}{l}\text { Group } \\
(5)\end{array}$ & $\begin{array}{l}\text { Group } \\
(6)\end{array}$ & $\begin{array}{l}\text { Group } \\
(7)\end{array}$ & $\begin{array}{c}\text { Significant } \\
\text { level }\end{array}$ \\
\hline $\begin{array}{l}\text { Absence of performance appraisal } \\
\text { criteria }\end{array}$ & 1.000 & 3.000 & 0.200 & 0.200 & 0.500 & 0.250 & 0.500 & 0.055 \\
\hline $\begin{array}{l}\text { The structure of the organisation is } \\
\text { inflexible }\end{array}$ & 0.333 & 1.000 & 0.167 & 0.167 & 0.500 & 0.200 & 0.500 & 0.035 \\
\hline Cost of energy & 5.000 & 6.000 & 1.000 & 1.000 & 6.000 & 2.000 & 7.000 & 0.294 \\
\hline Labour fees & 5.000 & 6.000 & 1.000 & 1.000 & 6.000 & 2.000 & 7.000 & 0.294 \\
\hline Careless distribution system & 2.000 & 2.000 & 0.167 & 0.167 & 1.000 & 0.200 & 0.500 & 0.056 \\
\hline Huge transportation fees & 4.000 & 5.000 & 0.500 & 0.500 & 5.000 & 1.000 & 7.000 & 0.204 \\
\hline $\begin{array}{l}\text { Absence of famous personal brand } \\
\text { Consistency index }(\mathrm{CI})=0.06\end{array}$ & 2.000 & 2.000 & 0.143 & 0.143 & 2.000 & 0.143 & 1.000 & 0.062 \\
\hline
\end{tabular}

The overall expenses of the provide link approach can also be divided into the expenses of unintended penalties (hazard expenses) and the expenses of investing in hazard reduction capabilities (hazard reduction expenses). The more you invest in hazard reduction, the lower is your hazard expenses. This is coupled via a mathematical algorithm utilized by Klindurfer and 
TABle 7: Analogy matrix of (O) group.

\begin{tabular}{|c|c|c|c|c|}
\hline (O) groups & Group (1) & Group (2) & Group (3) & Significant level \\
\hline Growing standards and enhancing contemporary technologies & 1.000 & 2.000 & 3.000 & 0.539 \\
\hline Globalisation and declined business obstacle & 0.500 & 1.000 & 2.000 & 0.297 \\
\hline $\begin{array}{l}\text { Modern overseas market } \\
\text { Consistency index }(\mathrm{CI})=0.08\end{array}$ & 0.333 & 0.500 & 1.000 & 0.164 \\
\hline
\end{tabular}

TABLE 8: Analogy matrix of (T) group.

\begin{tabular}{|c|c|c|c|c|c|c|c|c|}
\hline (T) groups & $\begin{array}{l}\text { Group } \\
\text { (1) }\end{array}$ & $\begin{array}{l}\text { Group } \\
\text { (2) }\end{array}$ & $\begin{array}{l}\text { Group } \\
\text { (3) }\end{array}$ & $\begin{array}{l}\text { Group } \\
(4)\end{array}$ & $\begin{array}{l}\text { Group } \\
\text { (5) }\end{array}$ & $\begin{array}{l}\text { Group } \\
(6)\end{array}$ & $\begin{array}{l}\text { Group } \\
(7)\end{array}$ & $\begin{array}{c}\text { Significant } \\
\text { levels }\end{array}$ \\
\hline The country's macroeconomic instability & 1.000 & 0.333 & 2.000 & 1.000 & 0.333 & 0.500 & 0.500 & 0.095 \\
\hline Rivalry & 3.000 & 1.000 & 1.000 & 2.000 & 4.000 & 3.000 & 1.000 & 0.239 \\
\hline $\begin{array}{l}\text { Political instability and related issues in the } \\
\text { region, especially the Middle East }\end{array}$ & 0.500 & 1.000 & 1.000 & 1.000 & 0.500 & 1.000 & 0.333 & 0.101 \\
\hline $\begin{array}{l}\text { Changing different mechanisms in world } \\
\text { markets }\end{array}$ & 1.000 & 0.500 & 1.000 & 1.000 & 3.000 & 1.000 & 0.500 & 0.124 \\
\hline Increased environmental pressures & 3.000 & 0.250 & 2.000 & 0.333 & 1.000 & 0.250 & 0.250 & 0.098 \\
\hline $\begin{array}{l}\text { Request for standardisation for clients around } \\
\text { the world }\end{array}$ & 2.000 & 0.333 & 1.000 & 1.000 & 2.000 & 1.000 & 0.333 & 0.113 \\
\hline $\begin{array}{l}\text { Income per unit is so low } \\
\text { Consistency index }(\mathrm{CI})=0.08\end{array}$ & 2.000 & 1.000 & 3.000 & 2.000 & 2.000 & 3.000 & 1.000 & 0.2311 \\
\hline
\end{tabular}

TABLe 9: Final priority rescores of SWOT elements via AHP.

\begin{tabular}{|c|c|c|c|c|}
\hline Groups & $\begin{array}{l}\text { Priority per } \\
\text { group }\end{array}$ & $\begin{array}{c}\text { Strengths, weaknesses, opportunities, and threats (SWOT) } \\
\text { elements }\end{array}$ & $\begin{array}{l}\text { Group inside factors priority } \\
\text { by AHP }\end{array}$ & $\begin{array}{l}\text { Final factors } \\
\text { priority }\end{array}$ \\
\hline (S) & 0.367 & $\begin{array}{c}\text { Original magnitude } \\
\text { Available skills and resources } \\
\text { Goods condition } \\
\text { Management of professional staff } \\
\text { Reliable market }\end{array}$ & $\begin{array}{l}0.057 \\
0.065 \\
0.400 \\
0.144 \\
0.334\end{array}$ & $\begin{array}{l}0.021 \\
0.024 \\
0.147 \\
0.053 \\
0.122 \\
\end{array}$ \\
\hline$(\mathrm{W})$ & 0.146 & $\begin{array}{c}\text { Absence of performance appraisal criteria } \\
\text { The structure of the organisation is inflexible } \\
\text { Cost of energy } \\
\text { Labour fees } \\
\text { Careless distribution system } \\
\text { Huge transportation fees } \\
\text { Absence of famous personal brand }\end{array}$ & $\begin{array}{l}0.055 \\
0.035 \\
0.294 \\
0.294 \\
0.056 \\
0.204 \\
0.062\end{array}$ & $\begin{array}{l}0.008 \\
0.005 \\
0.043 \\
0.043 \\
0.008 \\
0.030 \\
0.009\end{array}$ \\
\hline (O) & 0.365 & $\begin{array}{c}\text { Growing standards and enhancing contemporary technologies } \\
\text { Globalisation and declined business obstacle } \\
\text { Modern overseas market }\end{array}$ & $\begin{array}{l}0.539 \\
0.297 \\
0.164\end{array}$ & $\begin{array}{l}0.197 \\
0.108 \\
0.060\end{array}$ \\
\hline$(\mathrm{T})$ & 0.123 & $\begin{array}{c}\text { The country's macroeconomic instability } \\
\text { Rivalry } \\
\text { Political instability and related issues in the region, especially } \\
\text { the Middle East } \\
\text { Changing different mechanisms in world markets } \\
\text { Increased environmental pressures } \\
\text { Request for standardisation for clients around the world } \\
\text { Income per unit is so low }\end{array}$ & $\begin{array}{l}0.095 \\
0.239 \\
0.101 \\
0.124 \\
0.098 \\
0.113 \\
0.231\end{array}$ & $\begin{array}{l}0.012 \\
0.015 \\
0.012 \\
0.014 \\
0.028\end{array}$ \\
\hline
\end{tabular}

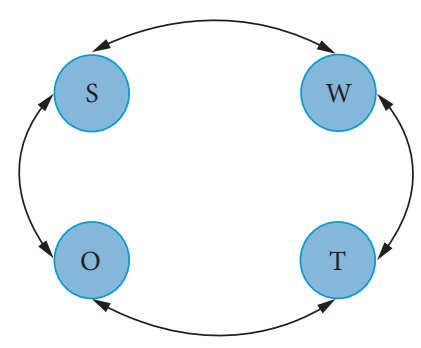

FIGURE 4: Interior dependence between SWOT elements. 
TABle 10: Interior dependency matrix.

\begin{tabular}{|c|c|c|c|}
\hline \multicolumn{4}{|c|}{ Interior dependence matrix via regarding "(S) Group" } \\
\hline (S) group & $(\mathrm{W})$ group & (O) group & Significant levels \\
\hline (W) group & 1.000 & 2.600 & 0.722 \\
\hline (O) group & 0.385 & 1.000 & 0.278 \\
\hline \multicolumn{4}{|c|}{ Consistency index $(\mathrm{CI})=0.00$} \\
\hline \multicolumn{4}{|c|}{ Interior dependence matrix via regarding “(W) Group” } \\
\hline (W) group & (S) group & (T) group & Significant levels \\
\hline (S) group & 1.000 & 3.200 & 0.762 \\
\hline$(\mathrm{T})$ group & 0.313 & 1.000 & 0.238 \\
\hline \multicolumn{4}{|c|}{ Consistency index $(\mathrm{CI})=0.00$} \\
\hline \multicolumn{4}{|c|}{ Interior dependence matrix via regarding "(O) Group” } \\
\hline (O) group & (T) group & (S) group & Significant levels \\
\hline (T) group & 1.000 & 3.600 & 0.783 \\
\hline (S) group & 0.278 & 1.000 & 0.217 \\
\hline \multicolumn{4}{|c|}{ Consistency index $(\mathrm{CI})=0.00$} \\
\hline \multicolumn{4}{|c|}{ Interior dependence matrix via regarding “(T) Group” } \\
\hline$(\mathrm{T})$ group & $(\mathrm{W})$ group & (O) group & Significant levels \\
\hline (W) group & 1.000 & 1.800 & 0.643 \\
\hline (O) group & 0.556 & 1.000 & 0.357 \\
\hline \multicolumn{4}{|c|}{ Consistency index $(\mathrm{CI})=0.00$} \\
\hline
\end{tabular}

TABle 11: An instance of dependency matrix (threats' group element affected weaknesses' group element).

\begin{tabular}{lccccc}
\hline Income per unit is so low (T) "group 7" & (W) group 3 & (W) group 4 & (W) group 6 & (W) group 3 & Significant level \\
\hline Cost of energy & 1.000 & 2.000 & 2.000 & 4.000 & 0.348 \\
Labour fees & 0.500 & 1.000 & 2.000 & 5.000 & 5.000 \\
Transportation fees & 0.500 & 0.500 & 1.000 & 1.000 & 0.364 \\
Absence of famous personal brand & 0.250 & 0.200 & 0.200 & 0.066 \\
Consistency index (CI) $=0.03$ & & & & \\
\hline
\end{tabular}

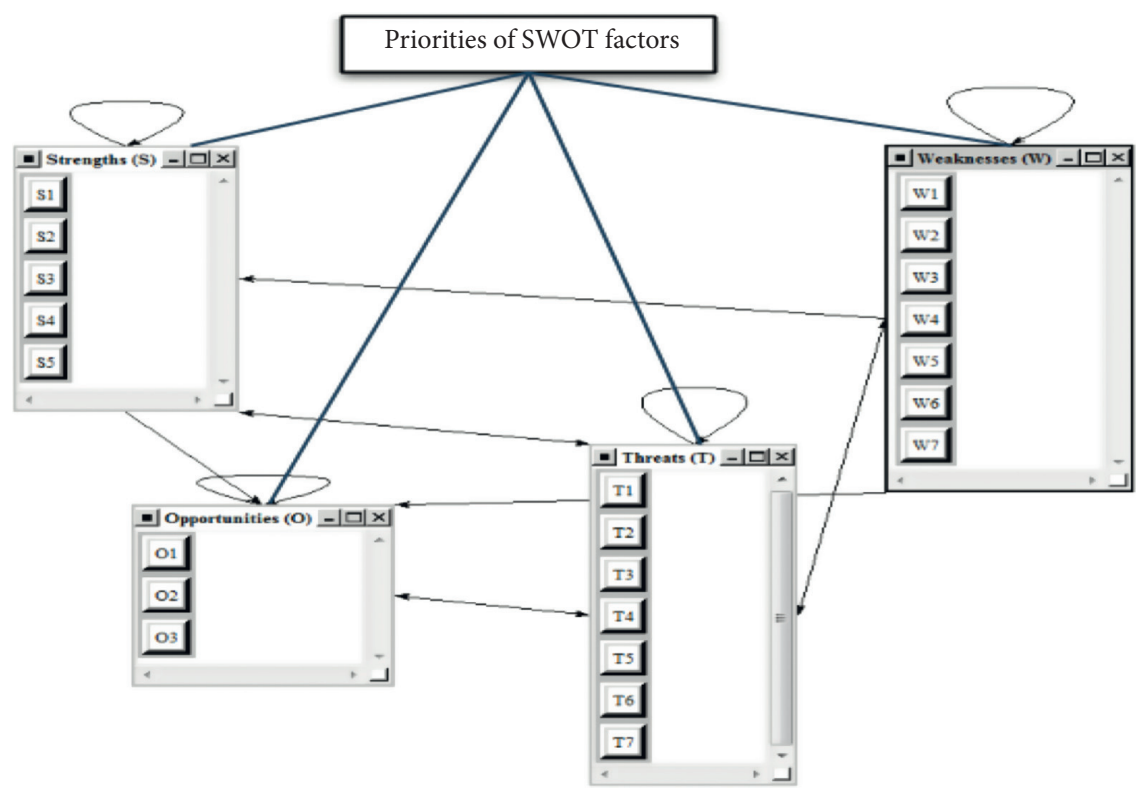

Figure 5: The network sketch of SWOT-ANP.

Saad, assuming that a firm is involved in the trade-off among the expenses of hazard reduction enterprising containing the expense for management systems and anticipated expenses for the disturbance [86]. Therefore, the mathematical algorithm is used to check the adaptability of such provide link techniques for different levels 
TABLE 12: Final priority scores of SWOT elements via ANP.

\begin{tabular}{|c|c|c|c|c|}
\hline Groups & $\begin{array}{l}\text { Priority per } \\
\text { group }\end{array}$ & $\begin{array}{c}\text { Strengths, weaknesses, opportunities, and threats (SWOT) } \\
\text { elements }\end{array}$ & $\begin{array}{l}\text { Group inside factors priority } \\
\text { by AHP }\end{array}$ & $\begin{array}{l}\text { Final factors } \\
\text { priority }\end{array}$ \\
\hline \multirow{5}{*}{ (S) } & \multirow{5}{*}{0.382} & Original magnitude & 0.076 & 0.029 \\
\hline & & Available skills and resources & 0.249 & 0.095 \\
\hline & & Goods condition & 0.371 & 0.142 \\
\hline & & Management of professional staff & 0.303 & 0.116 \\
\hline & & Reliable market & 0.001 & 0.000 \\
\hline \multirow{7}{*}{$(\mathrm{W})$} & \multirow{7}{*}{0.244} & Absence of performance appraisal criteria & 0.041 & 0.010 \\
\hline & & The structure of the organisation is inflexible & 0.010 & 0.002 \\
\hline & & Cost of energy & 0.308 & 0.075 \\
\hline & & Labour fees & 0.316 & 0.077 \\
\hline & & Careless distribution system & 0.001 & 0.000 \\
\hline & & Huge transportation fees & 0.210 & 0.051 \\
\hline & & Absence of famous personal brand & 0.114 & 0.028 \\
\hline \multirow{3}{*}{ (O) } & \multirow{3}{*}{0.255} & Growing standards and enhancing contemporary technologies & 0.003 & 0.001 \\
\hline & & Globalisation and declined business obstacle & 0.278 & 0.071 \\
\hline & & Modern overseas market & 0.718 & 0.183 \\
\hline \multirow{7}{*}{$(\mathrm{T})$} & \multirow{7}{*}{0.119} & The country's macroeconomic instability & 0.140 & 0.017 \\
\hline & & Rivalry & 0.255 & 0.030 \\
\hline & & $\begin{array}{c}\text { Political instability and related issues in the region, especially } \\
\text { the Middle East }\end{array}$ & 0.189 & 0.022 \\
\hline & & Changing different mechanisms in world markets & 0.136 & 0.016 \\
\hline & & Increased environmental pressures & 0.003 & 0.000 \\
\hline & & Request for standardisation for clients around the world & 0.138 & 0.016 \\
\hline & & Income per unit is so low & 0.140 & 0.017 \\
\hline
\end{tabular}

of effect and hazard. The use of mathematical algorithms in the social sciences has been well established [87].

5.4.1. Rigid Expenses. This is the usual hazard management approach that creates the hazard, and the hazard affects and uses the same scale for all types of hazards. This can be accomplished through normalisation. That is, the low effect is shown with an expense near to 0 , while the high effect is shown with an amount near to 1 :

$$
0 \leq p, i \leq 1 \text {. }
$$

Following Zsidisin et al., risk probability measures how often a detrimental event occurs (0: never and up to 1: very often) and risk impact expresses the significance of that loss (0: no loss and up to 1: catastrophic disappearance), cited in [88]. As for the adamant provide link, there is no investment in hazard reduction abilities. That is, on average, the overall costs $C_{\text {rig }}$ of a rigid supply chain consists of the occurrence costs only, and these expenses are equivalent to the hazard (= possibility $p$ effect $i$ ):

$$
C_{\text {rig }}(p, i)=p \cdot i
$$

5.4.2. Agility Expenses. This instance illustrates the identity of agile provide links. Consider an organisation with five compressed natural gas each producing unique products. Each year one of the compressed natural gas is ruined via the storm $(P=0.2)$. Nevertheless, it is not clear whether a more costly or cheaper compressed natural gas will be ruined next year (unknown effect). The provided link of the company is agile, if it accumulates extra capacity, enabling them to respond quickly to sudden compressed natural gas damage by standing together. Whatever the effect is (or a low-expense compressed natural gas), the budget before such dexterity is equivalent. The overall standard agile expenses are as follows.

Firstly, it is presumed that, in reality, achieving a $100 \%$ hazard reduction is impossible. Therefore, it is part of the expense of initial incurrence (illustrated via an element $\gamma_{\text {agi }}, 0 \prec \gamma_{\text {agi }} \prec 1$ still exists).

Secondly, the expenses of mitigating hazards using dexterity do not depend on the hazard effect realized. The more compressed natural gas is ruined each year by storm (and therefore the greater the hazard), the more agile the investment is because more capacity is needed. Hence, the expenses of mitigating hazards using dexterity depend on the likelihood of hazard. Expenses to mitigate hazards utilizing dexterity are counted as a percentage (illustrated via an element $\alpha, 0 \prec \alpha \prec 1)$ of $p$ in the current paper.

In conclusion, final dexterity expenses $C_{\text {agi }}$ are multiplexed into two factors: a section of the primary incidence expenses $\left(\gamma_{\text {agi }} \cdot p \cdot i\right)$ and hazard decrement expenses $(\alpha \cdot p)$. Only the preceding section relies on identified hazard effect:

$$
C_{\text {agi }}(p, i)=\gamma_{\text {agi }} \cdot p \cdot i+\alpha \cdot p .
$$

In Figure 6, the stiff overhead expenses associated with agile provide links depend on $i$. Assuming a constant $p$, if there is a large $i$ large, a adamant provide link is more efficient than a small $i$ and agile provide a link. However, a high constant expense element can change the $C_{\text {agi }}$ curve to a much higher degree than the $\mathrm{C}_{\text {rig }}$ curve. It happens that investing in dexterity (a) is high or when a hazard is high $(P)$ is too expensive. In short, the hazard reduction 


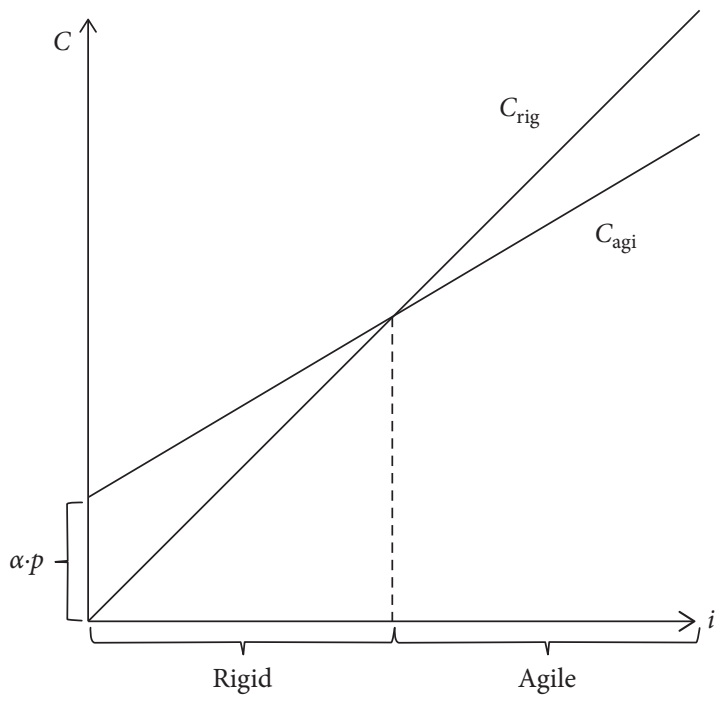

Figure 6: Analogy of the final fees of adamant with agile SCs. Source: authors.

expenses are not too high, if the hazard is low, and if the hazard is high, the agile provide link is more efficient than adamant. This is confirmed by the observation of Verstraete that flexibility should be created if a hazard is low and hazard is high [89].

5.4.3. Robustness Expenses. The following instance illustrates the characteristics of strong provide links. Let us presume a company has a factory in the United States. If the compressed natural gas is ruined by the storm next year, the provided link will be severely affected (for example, 0.8). Nevertheless, it is unclear whether this demolition will happen. The company's provide link is strong if it builds extra capacity in Europe's second compressed natural gas structure, providing the strength to withstand the sudden demolition of the US compressed natural gas. Whatever the likelihood of a US factory being ruined is investing in the firm before the event is the same. As a result, the expenses of mitigating hazards with the use of strength do not depend on the hazard. The more critical an American compressed natural gas is (and hence the higher the hazard effect), the more robust an investment it will be because additional herbs will be more expensive in Europe. Hence, the expenses of mitigating the hazards associated with the use of robust depend on the hazard effect. Hazard reduction expenses are calculated using the strength as a percentage (specified by an agent) of this article. Again, it is presumed that some of the expenses of initial incurrence still exist. A factor indicates this $\gamma_{\mathrm{rob}}$. In results, the overall expenses $C_{\text {rob }}$ of a strong provide link are compounded as pursue:

$$
C_{\mathrm{rob}}(p, i)=\gamma_{\mathrm{rob}} \cdot p \cdot i+\beta \cdot i
$$

As shown in Figure 6, the total expenses of adamant chains versus $p$ dependencies are shown. If $i$ has constant $i$ and there is a small and strong provide link for a large $p$, then the provide link is harder to choose. However, a constant

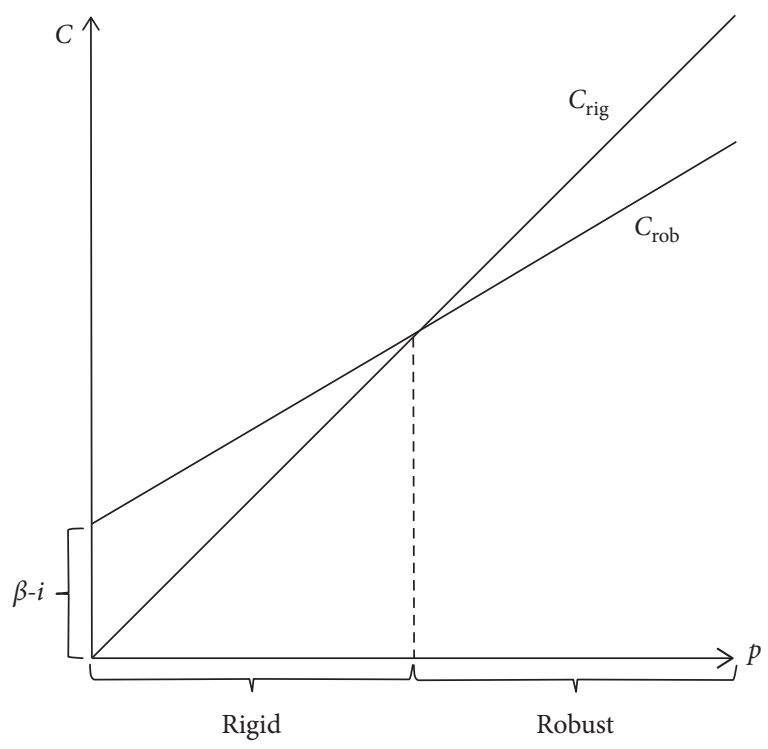

FIgure 7: Analogy of the final fees of adamant with robust SC (source: authors).

high expense element can change the $C_{\text {rob }}$ arc higher than the $C_{\text {rig }}$ arc. This occurs when investing in a firm (high) or when hazard is great (high $i$ ). In short, this means that the expenses of hazard reduction are not too high; if the hazard is higher and the hazard effect is low, a strong provide link is more efficient than adamant. This is carried out via Tong, who perceives that multifold suppliers allow one company to meet normal demand fluctuations and preserve continuing supply, and thus, allow one company to take hazards. In the event of a disorder, multiple sources reduce the hazard $[60,90,91]$.

5.4.4. Resilience Expenses. As converse before, a resilient provide link is likewise agile and strong. Accordingly, it is crucial to invest in hazard declination abilities to attain both agilities (expenses: $\alpha \cdot p$ ) and robustness (expenses: $\beta \cdot i$ ). In evaluation via a dexterity-only or a robustness-only technique, the hazard incidence expenses are similarly decreased. A factor indicates this $\gamma_{\text {res }}\left(\gamma_{\text {res }} \prec \gamma_{\text {agi }}, \gamma_{\text {rob }}\right)$. Within conclusion, the total expenses $C_{\text {res }}$ of a resilient provide link are compound as pursue (see Figure 7):

$$
C_{\text {res }}(p \cdot i)=\gamma_{\text {res }} \cdot p \cdot i+\alpha \cdot p+\beta \cdot i \text {. }
$$

Nevertheless, in this instance, it is extra effective than an agile and a strong SC if

$$
C_{\text {res }}(1,1)=\gamma_{\text {res }}+\alpha+\beta \prec \gamma_{\mathrm{agi}}+\alpha=C_{\mathrm{agi}}(1,1) ;
$$

moreover,

$$
C_{\text {res }}(1,1)=\gamma_{\text {res }}+\alpha+\beta \prec \gamma_{\text {rob }}+\beta=C_{\text {rob }}(1,1) .
$$

This is when the juncture application of agile and strong actions will result in a significant portion of the initial expenses of bearing (indicated through $g_{\text {res }}$ ) and again if the expenses of hazard reduction expenses ( $\alpha$ and $\beta$, commonly) are not too soaring. The abovementioned situation is generally accurate because when moving from a firm to a flexible technique, extra 


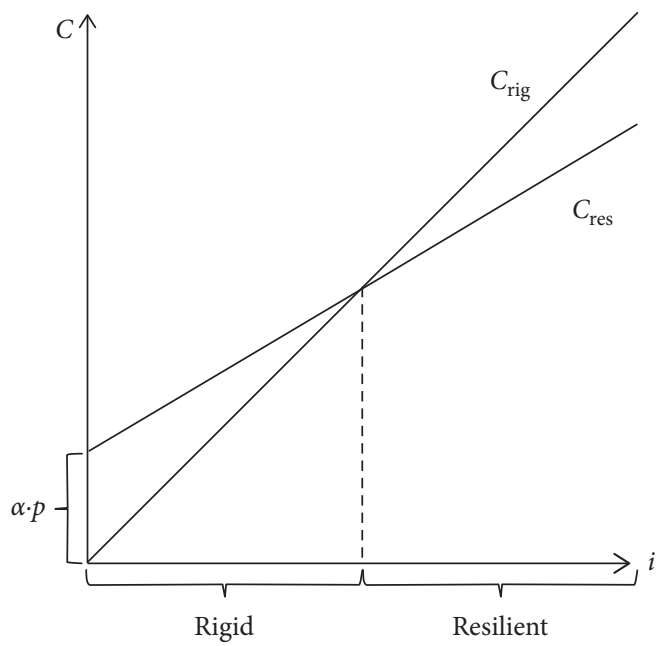

(a)

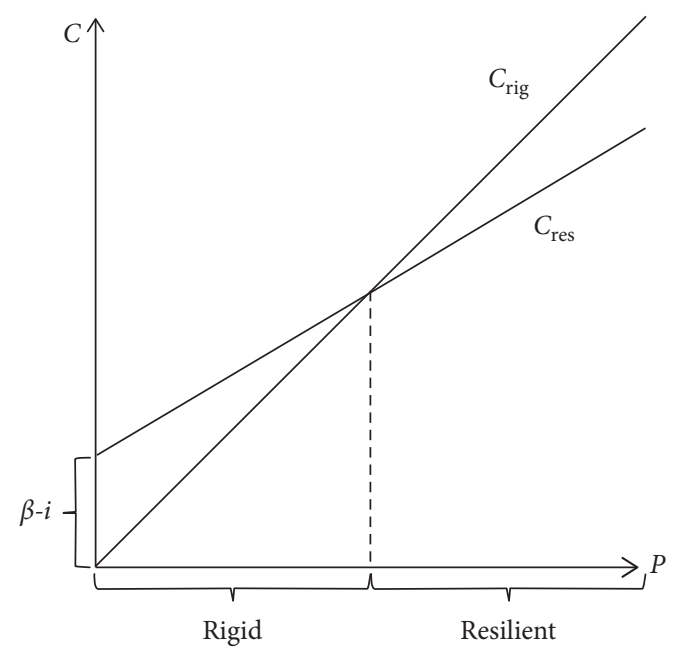

(b)

FIgUre 8: Analogy of the final fees of adamant with resilient SCs. Source: authors.

TABLE 13: $t$-test for the first hypothesis.

The value of test $=3$

\begin{tabular}{|c|c|c|c|c|c|c|}
\hline \multirow{2}{*}{$\begin{array}{l}\text { The test } \\
\text { statistics }\end{array}$} & \multirow{2}{*}{$\begin{array}{l}\text { Degrees of } \\
\text { freedom }\end{array}$} & \multirow{2}{*}{ The level of significance } & \multirow{2}{*}{$\begin{array}{l}\text { The differences among the } \\
\text { average }\end{array}$} & \multicolumn{2}{|c|}{$\begin{array}{l}\text { The average confidence } \\
\text { interval of } 95 \%\end{array}$} & \multirow{2}{*}{ Hypotheses } \\
\hline & & & & $\begin{array}{c}\text { Lower } \\
\text { limit }\end{array}$ & $\begin{array}{l}\text { Upper } \\
\text { limit }\end{array}$ & \\
\hline 10.65 & 199 & 0.000 & 0.66 & 0.53 & 0.87 & $\mathrm{H} 1$ \\
\hline 11.19 & 199 & 0.000 & 0.56 & 0.46 & 0.66 & $\mathrm{H} 2$ \\
\hline 16.35 & 199 & 0.000 & 0.81 & 0.71 & 0.90 & $\mathrm{H} 3$ \\
\hline 9.21 & 199 & 0.000 & 0.43 & 0.34 & 0.53 & $\mathrm{H} 4$ \\
\hline
\end{tabular}

Source: authors.

TABle 14: Statistics related to the first hypothesis.

\begin{tabular}{lcccc}
\hline Sample size & Average & Standard deviation (SD) & Standard error & Hypotheses \\
\hline 200 & 3.66 & 0.87 & 0.06 & H1 \\
200 & 3.56 & 0.71 & 0.05 & H2 \\
200 & 3.81 & 0.70 & 0.05 & H3 \\
200 & 3.43 & 0.67 & 0.04 & H4 \\
\hline
\end{tabular}

Source. Authors.

investment in agile valuations reduces (and vice versa) the ratio of the expenses of initial occurrence (see Figure 8).

\section{Data Evaluation}

H1: the empowerment of sufficient SCs dexterity.

As stated in Table 13, the test statistic value 10.65 is higher than 1.96, upper and lower limit signs are positive and significance level of 0.000 , which is less than 0.05 , in accordance to the evidence, we can conclude that the $H_{0}$ hypothesis is rejected and the hypothesis is accepted. The $H_{0}$ hypothesis as a lack of empowerment effect on providing link dexterity enabling effect on providing link dexterity and hypotheses of this study was to define the test and the
$H_{0}$ hypothesis is rejected, and as the same lack of effectiveness in terms of employee empowerment, significant effect on SC agility is accepted. As stated in Table 14, the mean comments 3.66 are also higher than the average hypothetical 3 . This means that the staff has considered the relationship between them. $\mathrm{H} 2$ : sufficient SC dexterity is the ability dexterity.

As stated in Table 13, the test statistic value 11.19 is higher than 1.96, upper and lower limit signs are positive and significance level of 0.000 , which is less than 0.05 . As stated in the evidence, we can conclude that the $H_{0}$ hypothesis is rejected and the hypothesis is accepted. The $H_{0}$ hypothesis as lack of effect on providing link dexterity and dexterity capability's hypothesis of this study was defined as the effect of 
provide link dexterity capabilities that the test rejects the $H_{0}$ hypothesis that the lack of effectiveness and in terms of staff ability's dexterity significant effect on providing link dexterity is accepted. As stated in Table 14, average is 3.56 comments which is also higher than criterion 3 . This means that the staff has considered the relationship between them.

H3: sufficient SC dexterity is driving dexterity.

As stated in Table 13 and 14, the test statistic value 16.35 is higher than 1.96, upper and lower limit signs are positive and significance level of 0.000 , which is less than 0.05 , as a result. As stated in the evidence, we can conclude that the $H_{0}$ hypothesis is rejected, and the hypothesis is accepted. The $H_{0}$ hypothesis as lack of dexterity stimulating effect on provide link dexterity and hypothesis of this study was defined as the effect of provide link dexterity drivers on the dexterity that the test rejects the $H_{0}$ hypothesis that the lack of effectiveness and from the perspective of employees' dexterity triggers a significant effect on providing link dexterity is accepted as stated in Table 6 in Average Reviews 3/81, which is also higher than criterion 3. This means that the staff has considered the relationship between them.

H4: expense-effective SC dexterity.

As stated in Table 13, the test statistic value 9.21 is higher than 1.96, upper and lower limit signs are positive and significance level of 0.000 , which is less than 0.05 ; as stated in the evidence, we can conclude that the $H_{0}$ hypothesis is rejected, and the hypothesis is accepted. The $H_{0}$ hypothesis as lack of effect on the cost of the SC agility and hypotheses of this study were defined as the effect of cost on SC agility and in this test the $\mathrm{HO}$ hypothesis is rejected, and the same lack of effectiveness and in terms of staff costs has a significant effect on SC agility which is accepted. As stated in Table 14, in average reviews, it is 3.43 , which is also higher than criterion 3 . This means that the staff has considered the relationship between them.

\section{Conclusion}

In summary, the results of the research hypotheses are as follows.

7.1. Enabling the Effective SCs Agility. The test statistic is higher than the 10.65 and 1.96, upper and lower limit signs' mean, and positive significance level of 0.000 , which is less than 0.05; as a result, as stated by this testimony, it can be said that the $H_{0}$ hypothesis is rejected, and the hypothesis is accepted. This means that staff has considered the relationship among high, and this suggests that empowerment is effective to provide link dexterity.

7.2. Sufficient SC Agility Is the Ability Agility. 11.19 and 1.96 test statistics are higher than the upper limit and lower average positive signs and the significance level of 0.000 , which is less than 0.05; as a result, as stated by the evidence, we can conclude that the $H_{0}$ hypothesis is rejected, and the hypothesis is accepted. This means that staff has considered the relationship among high, and this suggests that sufficiently provide link dexterity is the ability dexterity.

7.3. Agility Driver on the Agility of the SC Is Effective. The test statistic is higher than the 16.35 and 1.96, upper and lower limit signs mean and positive significance level of 0.000 , which is less than 0.05; as a result, as stated by the evidence, we can conclude that the $H_{0}$ hypothesis is rejected, and the hypothesis is accepted. This means that staff has considered the relationship among high, and this suggests that sufficiently provide link dexterity is driving dexterity.

7.4. Expense Effective SCs Agility. The test statistic is higher than the value of 9.21 and 1.96, upper and lower limit signs mean and an actual significance level of 0.000 , which is less than 0.05 ; as a result, due to the evidence, we can conclude that the $H_{0}$ hypothesis is rejected, and the hypothesis is accepted. This means that staff has considered the relationship among high, and this suggests the expense-effective provide link dexterity.

7.5. Proposals of Research Findings. This paper presents a "hazard dexterity" algorithm from the provide link that has a definite view of the hazard management perspective. This algorithm includes "hazard elements," later referred to as "provide link complexity"; "Provide link Diversity"; and "Major Provide link Events." These different hazard categories require agile techniques that need to be improved and implemented progressively. Using this algorithm as a prescribed algorithm for providing link modeling is proposed for a path to gain better supply chain performance, satisfy client needs, and do then at the end provide link expense.

The suggested algorithm is heavily affected via Six Sigma's "Modeling for X" algorithm. This algorithm is not only known as "modeling for providing link hazard" but has also been shown to be "modeling for providing link dexterity" in previous research [49]. The idea is that depending on the preference of the scientist/company, the "attitude" of $X$ can be replaced.

Future research needs to be improved to examine especially the implementation of this algorithm in real organisations. It might also be through action study where the algorithm is first used to help organisations in growing techniques for delivering a significant provide link. The outcomes of the current research should approve the effectiveness of this algorithm.

Rank and prioritise dexterity drivers of each of the indicators in the variable specified. The structure, modeling capabilities, and system variable dexterity drivers are involved in defining quality. Given the positive effect on the quality, the system is proposed to provide link dexterity by enhancing product quality by international standards and updating technology; product quality assessment subsequently increased rivalry and increased market share. Due to 
the effect of provide link dexterity is suggested that among car modeling and the modeling of effective communication be established to shape and structure of this product in use and application efficiency is higher.

Rank and priority of each of the indexes are specified in the variable abilities' dexterity. The number of strategic and vital parts affected by the sanctions, delivery time, expense, flexibility, and technical capabilities in explaining the varying abilities contributed dexterity. Though reverse engineering can be found in many technologies, its usage in parts surrounded by localizing the product can be reduced to the percentage of the product expense, and also due to geographical conditions and factors affecting the production of steel products and tools, it can be used in addition to the flexible production process which has a significant effect on commodity expenses and delivery time.

Ranking the priority of each of the indexes is specified in empowerment. To arrange training of human sources, the procurement of trust between users and information technology development has played a role in explaining empowerment. It is suggested that given the positive effect on provide link dexterity training of human sources is suggested that by holding training courses for human sources managers in the organization and increase the company's provide link dexterity. Owing to the increasing improvement of IT and the scientific capabilities of nearby countries (India and Russia) to Iran can be of human sources of these countries and attending these seminars also applied the scientific arena to be added.

Rank and priority of each of the indexes are specified in variable expenses. The expenses of operations, financial condition, and delay in project expenses have played a role in explaining the variable expenses; fixed expenses of production can be produced with solutions, such as proximity to sources of raw materials, hiring local workers, and reducing capital spending on agents, as well as capital expenditures rather than overhead expenses of production (e.g., the vehicle for rent), and can significantly reduce the product expense only in Iran, but this may be applicable.

\section{Data Availability}

The data used to support the findings of this study are included within the article.

\section{Conflicts of Interest}

The authors declare that they have no conflicts of interest.

\section{References}

[1] J. R. Stock and D. M. Lambert, Strategic Logistics Management, McGraw-Hill/Irwin, New York, NY, USA, 4th edition, 2001.

[2] D. M. Lambert, M. C. Cooper, and J. D. Pagh, "Supply chain management: implementation issues and research opportunities," The International Journal of Logistics Management, vol. 9, no. 2, pp. 1-20, 1998.

[3] J. W. Forrester, Urban Dynamics, MIT Press, Cambridge, MA, USA, 1969.
[4] R. Azimi, A. Yazdani-Chamzini, M. M. Fouladgar, E. K. Zavadskas, and M. H. Basiri, "Ranking the strategies of mining sector through anp and topsis in a swot framework/ gavybos sektoriaus strategijų rangavimas taikant anp, topsis Ir ssgg metodus," Journal of Business Economics and Management, vol. 12, no. 4, pp. 670-689, 2011.

[5] G. Houben, K. Lenie, and K. Vanhoof, "A knowledge-based SWOT-analysis system as an instrument for strategic planning in small and medium sized enterprises," Decision Support Systems, vol. 26, no. 2, pp. 125-135, 1999.

[6] V. Wickramasinghe and S. Takano, "Application of combined SWOT and analytic hierarchy process AHP for tourism revival strategic marketing planning: a case of Sri Lanka tourism," Journal of the Eastern Asia Society for Transportation Studies, vol. 8, pp. 954-969, 2010.

[7] J. Gallego-Ayala and D. Juízo, "Strategic implementation of integrated water resources management in Mozambique: an A'WOT analysis," Physics and Chemistry of the Earth, Parts A/ $B / C$, vol. 36, no. 14-15, pp. 1103-1111, 2011.

[8] İ. Yüksel and M. Dağdeviren, "Using the analytic network process (ANP) in a SWOT analysis-a case study for a textile firm," Information Sciences, vol. 177, no. 16, pp. 3364-3382, 2007.

[9] M. Kurttila, M. Pesonen, J. Kangas, and M. Kajanus, "Utilizing the analytic hierarchy process (AHP) in SWOT analysis-a hybrid method and its application to a forest-certification case," Forest Policy and Economics, vol. 1, no. 1, pp. 41-52, 2000.

[10] C.-Y. Gao and D.-H. Peng, "Consolidating SWOT analysis with nonhomogeneous uncertain preference information," Knowledge-Based Systems, vol. 24, no. 6, pp. 796-808, 2011.

[11] S. Lee and P. Walsh, "SWOT and AHP hybrid model for sport marketing outsourcing using a case of intercollegiate sport," Sport Management Review, vol. 14, no. 4, pp. 361-369, 2011.

[12] J. Kangas, M. Kurttila, M. Kajanus, and A. Kangas, "Evaluating the management strategies of a forestland estate-the S-O-S approach," Journal of Environmental Management, vol. 69, no. 4, pp. 349-358, 2003.

[13] M. Pesonen, M. Kurttila, J. Kangas, M. Kajanus, and P. Heinonen, “Assessing the priorities using A'WOT among resource management strategies at the Finnish forest and park service," Forest Science, vol. 47, pp. 534-541, 2001.

[14] H. Shinno, H. Yoshioka, S. Marpaung, and S. Hachiga, "Quantitative SWOT analysis on global competitiveness of machine tool industry," Journal of Engineering Design, vol. 17, no. 3, pp. 251-258, 2006.

[15] O. Arslan and I. D. Er, "SWOT analysis for safer carriage of bulk liquid chemicals in tankers," Journal of Hazardous Materials, vol. 154, no. 1-3, pp. 901-913, 2008.

[16] İ. Yüksel and A. Akin, "Determination strategy in business with the analytic hierarchy process," Doğuş University Journal, vol. 7, no. 2, pp. 254-268, 2006.

[17] A. Taşkın and A. F. Güneri, "Strateji geliştirmede A'WOT hibrit metodu kullanımı ve Türk kimya sektöründe bir uygulama çalışması, V," National Production Research Symposium Proceedings Book UAS’05, pp. 503-507, 2005.

[18] O. Arslan and O. Turan, "Analytical investigation of marine casualties at the Strait of Istanbul with SWOT-AHP method," Maritime Policy \& Management, vol. 36, no. 2, pp. 131-145, 2009.

[19] A. Kandakoglu, M. Celik, and I. Akgun, "A multi-methodological approach for shipping registry selection in maritime transportation industry," Mathematical and Computer Modelling, vol. 49, no. 3-4, pp. 586-597, 2009.

[20] A. Ostrega, F. De Felice, and A. Petrillo, "ANP-SWOT approach to minimize environmental impacts due to mining 
activities," in Proceedings of the ISAHP 2011 Symposium, Naples, Italy, June 2011.

[21] M. M. Fouladgar, S. H. Yakhchali, A. Y. Chamzini, and M. H. Basiri, "Evaluating the strategies of Iranian mining sector using an integrated model," in Proceedings of the International Conference on Financial Management and Economics, pp. 58-63, Hong Kong, Hong Kong, July 2011.

[22] X. Deng and Y. Deng, "D-AHP method with different credibility of information," Soft Computing, vol. 23, no. 2, pp. 683-691, 2019.

[23] W. Kusdiana, A. Nugroho, S. Sutrisno, and A. Rahman, "High pressure pump damage analysis mpk mtu 16 v 4000 m 90 series on kri parchim class using swot method," International Journal of Asro-Sttal, vol. 11, no. 1, pp. 144-150, 2020.

[24] S. Aydin and C. Kahraman, "Evaluation of firms applying to malcolm baldrige national quality award: a modified fuzzy AHP method," Complex \& Intelligent Systems, vol. 5, no. 1, pp. 53-63, 2019.

[25] X. Hu, B. Sun, and X. Chen, "Double quantitative fuzzy rough set-based improved AHP method and application to supplier selection decision making," International Journal of Machine Learning and Cybernetics, vol. 11, no. 1, pp. 153-167, 2020.

[26] N. F. Aziz, S. Sorooshian, and F. Mahmud, "MCDM-AHP method in decision makings," ARPN Journal of Engineering and Applied Sciences, vol. 11, no. 11, pp. 7217-7220, 2016.

[27] S. A. Erdogan, J. Šaparauskas, and Z. Turskis, "Decision making in construction management: AHP and expert choice approach," Procedia Engineering, vol. 172, pp. 270-276, 2017.

[28] A. Camci, G. T. Temur, and A. Beskese, "CNC router selection for SMEs in woodwork manufacturing using hesitant fuzzy AHP method," Journal of Enterprise Information Management, vol. 31, no. 4, pp. 529-549, 2018.

[29] P. Yarahmadi, S. Dashti, and G. R. Sabzghabaei, “Assessment and ranking of contractors from the point of view HSE performance using Multi-criteria decision making method (AHP and TOPSIS) in Imam Khomeini port complex," Journal of Occupational Hygiene Engineering, vol. 4, no. 4, pp. 70-80, 2018.

[30] A. Calabrese, R. Costa, N. Levialdi, and T. Menichini, "Integrating sustainability into strategic decision-making: a fuzzy AHP method for the selection of relevant sustainability issues," Technological Forecasting and Social Change, vol. 139, pp. 155-168, 2019.

[31] M. Taleai, M. Safarpour, and G. Javadi, "Potential evaluation for establishment of solar power plants using multi-criteria decision-making methods: OWA and TOPSIS (case study: Qazvin-Iran)," The Journal of Spatial Planning, vol. 22, no. 4, pp. 1-27, 2019.

[32] F. Sari, İ. Kandemir, D. A. Ceylan, and A. Gül, "Using AHP and PROMETHEE multi-criteria decision making methods to define suitable apiary locations," Journal of Apicultural Research, pp. 1-12, 2020.

[33] T. L. Saaty, The Analytical Hierarchy Process, McGraw-Hill, New York, NY, USA, 1980.

[34] T. L. Saaty and L. G. Vargas, Prediction, Projection and Forecasting, Kluwer Academic, Boston, MA, USA, 1991.

[35] H. L. Lee, C. Billington, and B. Carter, "Hewlett-Packard gains control of inventory and service through design for localization," Interfaces, vol. 23, no. 4, pp. 1-11, 1993.

[36] H. L. Lee, "Design for SCM: concepts and examples," in Perspectives in Operations Management, R. Sarin, Ed., pp. 43-65, Kluwer, Boston, MA, USA, 1993.
[37] H. L. Lee and C.. Billington, "Managing SC inventory: pitfalls and opportunities," Sloan Management Review, vol. 33, no. 3, pp. 65-73, 1992.

[38] H. L. Lee and C. S. Tang, "Modelling the costs and benefits of delayed product differentiation," Management Science, vol. 43, no. 1, pp. 40-53, 1997.

[39] H. L. Lee and M. M. Sasser, "Product universality and design for supply chain management," Production Planning \& Control, vol. 6, no. 3, pp. 270-277, 1995.

[40] H. L. Lee, "Aligning supply chain strategies with product uncertainties," California Management Review, vol. 44, no. 3, pp. 105-119, 2002.

[41] H. L. Lee, "The triple-A SC," Harvard Business Review, 2004.

[42] C. Laval, M. Feyhl, and S. Kakouros, "Hewlett-packard combined OR and expert knowledge to design its supply chains," Interfaces, vol. 35, no. 3, pp. 238-247, 2005.

[43] M. Christopher and H. Lee, "Mitigating supply chain risk through improved confidence," International Journal of Physical Distribution \& Logistics Management, vol. 34, no. 5, pp. 388-396, 2004.

[44] M. Baramichai, E. W. Zimmers, and C. A. Marangos, "Agile supply chain transformation matrix: an integrated tool for creating an agile enterprise," Supply Chain Management: An International Journal, vol. 12, no. 5, pp. 334-348, 2007.

[45] W. J. Tolone, "Virtual situation rooms: connecting people across enterprises for supply-chain agility," Computer-Aided Design, vol. 32, no. 2, pp. 109-117, 2000.

[46] C.-L. Yang, S.-P. Chuang, and R.-H. Huang, "Manufacturing evaluation system based on AHP/ANP approach for wafer fabricating industry," Expert Systems with Applications, vol. 36, no. 8, pp. 11369-11377, 2009.

[47] J. E. Leal, “AHP-express: a simplified version of the analytical hierarchy process method," MethodsX, vol. 7, Article ID 100748, 2020.

[48] R. Rivera-Castro, I. Nazarov, Y. Xiang, A. Pletneev, I. Maksimov, and E. Burnaev, "Demand forecasting techniques for build-to-order lean manufacturing SCs," in Proceedings of the International Symposium on Neural Networks, Springer, Moscow, Russia, pp. 213-222, July 2019.

[49] R. W. Monroe and P. R.. Martin, "Designing agility into the SC," in Proceedings of the ICAM International Conference on Agile Manufacturing, Kalamazoo, MI, USA, 2008.

[50] R. Monczka, R. Trent, and R. Handfield, Purchasing and SCM, Southwestern Publishing, Cincinnati, OH, USA, 2nd edition, 2001.

[51] A. G. de Kok and S. C. Graves, Handbooks in Operations Research and Management Science: SCM: Design, Coordination and Operation, Vol. 11, Elsevier, Amsterdam, Netherlands, 2003.

[52] B. Hazen and A. Ellinger, Logistics Customer Service Revisited, Emerald Publishing Limited, Bingley, UK, 2019.

[53] D. Simchi-Levi, P. Kaminsky, and E. Simchi-Levi, Designing and Managing the SC: Concepts, Strategies and Case Studies, McGraw-Hill, New York, NY, USA, 3rd edition, 2008.

[54] M. Dong, "Development of supply chain network robustness index," International Journal of Services Operations and Informatics, vol. 1, no. 1-2, pp. 54-66, 2006.

[55] Y. Meepetchdee and N. Shah, "Logistical network design with robustness and complexity considerations," International Journal of Physical Distribution \& Logistics Management, vol. 37, no. 3, pp. 201-222, 2007.

[56] A. H. Dekker and B. D. Colbert, "Network robustness and graph topology," in Proceedings of the Twenty-Seventh Australasian Computer Science Conference ACSC 2004, Australian 
Computer Society, Dunedin, New Zealand, pp. 359-368, January 2004.

[57] B. E. Asbjørnslett, "Assessing the vulnerability of SCs," in SC Risk: A Handbook of Assessment, Management, and Performance, G. A. Zsidisin and B. Ritchie, Eds., pp. 15-33, Springer, Berlin, Geramay, 2008.

[58] Y. Mo and T. P. Harrison, Edited by J. Geunes, Ed., "A conceptual framework for robust SC design under demand uncertainty," in SC Optimization, P. M. Pardalos, Ed., pp. 243-264, Springer, New York, NY, USA, 2005.

[59] T. P. Harrison, "Principles for the strategic design of SCs," in The Practice of SCM: Where Theory and Application Converge, T. P. Harrison, H. L. Lee, and J. J. Neale, Eds., pp. 3-12, Springer, Berlin, Germay, 2005.

[60] C. S. Tang, "Robust strategies for mitigating supply chain disruptions," International Journal of Logistics Research and Applications, vol. 9, no. 1, pp. 33-45, 2006.

[61] R. Albert and A.-L. Barabási, "Statistical mechanics of complex networks," Reviews of Modern Physics, vol. 74, no. 1, pp. 47-97, 2002.

[62] J. B. Rice and F. Caniato, "Building a secure and resilient supply network," SCM Review, vol. 7, no. 5, pp. 22-30, 2003.

[63] R. B. Handfield, J. Blackhurst, D. Elkins, and C. W. Craighead, "A framework for reducing the impact of disruptions to the SC: observations from multiple executions," in SC Risk Management: Minimizing Disruptions in Global Sourcing, R. B. Handfield and K. McCormack, Eds., pp. 29-50, Auerbach Publications, Boca Raton, FL, USA, 2008.

[64] S. Y. Ponomarov and M. C. Holcomb, "Understanding the concept of supply chain resilience," The International Journal of Logistics Management, vol. 20, no. 1, pp. 124-143, 2009.

[65] Y. Sheffi and J. B. Rice, "A SC view of the resilient enterprise," MIT Sloan Management Review, vol. 47, no. 1, pp. 40-48, 2005.

[66] G. T. Stewart, R. Kolluru, and M. Smith, "Leveraging publicprivate partnerships to improve community resilience in times of disaster," International Journal of Physical Distribution \& Logistics Management, vol. 39, no. 5, pp. 343-364, 2009.

[67] M. Christopher and C. Rutherford, "Creating SC resilience through agile six sigma," Critical Eye, pp. 24-28, 2004.

[68] M. Christopher and H. Peck, "Building the resilient supply chain," The International Journal of Logistics Management, vol. 15, no. 2, pp. 1-14, 2004.

[69] J. Fiksel, "Sustainability and resilience: toward a systems approach," Sustainability: Science, Practice and Policy, vol. 2, no. 2, pp. 14-21, 2006.

[70] G. Chow, T. D. Heaver, and L. E. Henriksson, "Logistics performance," International Journal of Physical Distribution \& Logistics Management, vol. 24, no. 1, pp. 17-28, 1994.

[71] J. Angelis, R. Conti, C. Cooper, and C. Gill, "Building a highcommitment lean culture," Journal of Manufacturing Technology Management, vol. 22, no. 5, pp. 569-586, 2011.

[72] T. A. Boyle, M. Scherrer-Rathje, and I. Stuart, "Learning to be lean: the influence of external information sources in lean improvements," Journal of Manufacturing Technology Management, vol. 22, no. 5, pp. 587-603, 2011.

[73] M. L. Fisher, "What is the right SC for your product?" Harvard Business Review, vol. 75, no. 2, pp. 105-116, 1997.

[74] M. Christopher and D. Towill, "An integrated model for the design of agile supply chains," International Journal of Physical Distribution \& Logistics Management, vol. 31, no. 4, pp. 235-246, 2001.

[75] E. Selldin and J. Olhager, "Linking products with supply chains: testing Fisher's model," Supply Chain Management: An International Journal, vol. 12, no. 1, pp. 42-51, 2007.
[76] G. Liu, R. Shah, and R. G. Schroeder, "Managing demand and supply uncertainties to achieve mass customization ability," Journal of Manufacturing Technology Management, vol. 21, no. 8, pp. 990-1012, 2010.

[77] S. Y. Sun, M. H. Hsu, and W. J. Hwang, "The impact of alignment between supply chain strategy and environmental uncertainty on SCM performance," Supply Chain Management: An International Journal, vol. 14, no. 3, pp. 201-212, 2009.

[78] M. Christopher, H. Peck, and D. Towill, "A taxonomy for selecting global supply chain strategies," The International Journal of Logistics Management, vol. 17, no. 2, pp. 277-287, 2006.

[79] Y. Liu, Y. Li, and Z. Wei, "How organizational flexibility affects new product development in an uncertain environment: evidence from China," International Journal of Production Economics, vol. 120, no. 1, pp. 18-29, 2009.

[80] P. Cicconi, V. Castorani, M. Germani, M. Mandolini, and A. Vita, "A multi-objective sequential method for manufacturing cost and structural optimization of modular steel towers," Engineering with Computers, vol. 36, no. 2, pp. 475-497, 2020.

[81] J. Kangas, M. Pesonen, M. Kurttila, and M. Kajanus, “A'WOT: Integrating the AHP with SWOT Analysis," in Proceedings of the 6th ISAHP 2001, pp. 189-198, Berne, Switzerland, 2001.

[82] M. Kajanus, J. Kangas, and M. Kurttila, "The use of value focused thinking and the A'WOT hybrid method in tourism management," Tourism Management, vol. 25, no. 4, pp. 499-506, 2004.

[83] T. L. Saaty and M. Takizawa, "Dependence and independence: from linear hierarchies to nonlinear networks," European Journal of Operational Research, vol. 26, no. 2, pp. 229-237, 1986.

[84] S. M. Hatefi and J. Tamošaitienè, “An integrated fuzzy DEMATEL-fuzzy ANP model for evaluating construction projects by considering interrelationships among risk factors," Journal of Civil Engineering and Management, vol. 25, no. 2, pp. 114-131, 2019.

[85] B. Choubin, O. Rahmati, N. Tahmasebipour, B. Feizizadeh, and H. R. Pourghasemi, "Application of fuzzy analytical network process model for analyzing the gully erosion susceptibility," in Natural Hazards GIS-Based Spatial Modeling Using Data Mining Techniques, pp. 105-125, Springer, Cham, Switzerland, 2019.

[86] P. R. Kleindorfer and G. H. Saad, "Managing disruption risks in SCs," Production and Operations Management, vol. 14, no. 1, pp. 53-68, 2005.

[87] R. Frankel, D. Naslund, and Y. Bolumole, "The "white space" of logistics research: a look at the role of methods usage," Journal of Business Logistics, vol. 26, no. 2, pp. 185-209, 2005.

[88] M. M. Parast and M. Shekarian, "The impact of SC disruptions on organisational performance: a literature review," in Revisiting SC Risk, pp. 367-389, Springer, Cham, Switzerland, 2019.

[89] C. Verstraete, "Share and share alike," CSCMP SC Quarterly, vol. 2, p. 34, 2008.

[90] R. Tullous and R. Lee Utrecht, "Multiple or single sourcing?" Journal of Business \& Industrial Marketing, vol. 7, no. 3, pp. 5-18, 1992.

[91] A. Haas, "Logistics and SC intelligence," in Integration of Information Flow for Greening SCM, pp. 111-129, Springer, Cham, Switzerland, 2020. 